Chapter 2

\title{
Genomic Heterogeneity of Hepatitis Viruses (A-E): Role in Clinical Implications and Treatment
}

\author{
Zahid Hussain \\ Additional information is available at the end of the chapter \\ http://dx.doi.org/10.5772/55231
}

\section{Introduction}

Hepatitis is an inflammation of the liver. There are at least five different viruses causing hepatitis. Each of the five major hepatitis viruses, hepatitis A virus (HAV), hepatitis B virus (HBV), hepatitis $\mathrm{C}$ virus (HCV), delta hepatitis virus (HDV) and hepatitis E virus (HEV) belong to a separate family. Currently, all these viral hepatitis (A-E) have been classified into different genotypes and subgenotypes. Several factors, including viral genotypes have been reported to be associated with disease progression and treatment response. Consequently, documentation of genotype recently have been proved to be a valuable tool not only for epidemiological reasons but also for clinical implications and treatment.

\section{Hepatitis A virus}

HAV is a member of the Hepatovirus genus of Picornaviridae family. HAV is a non-enveloped (naked), linear, single stranded RNA virus of an icosahedral symmetry measuring 27-32 nm in diameter [1]. HAV infection is hyper-endemic in vast areas of the world, with approximately 1.5 million clinical cases per year [2]. The worldwide distribution is uneven and is based on determinants such as socioeconomic conditions and geographic factors [3-5]. In developing countries, the incidence of disease in adults is relatively low because of exposure to the virus in childhood. Most adults in these areas show prevalence of antibodies against hepatitis A. In developed world endemicity is usually very low and clinical cases occur almost exclusively in adults [6,7]. The variable age distribution among hepatitis A patients in developing and developed countries is a consequence of differing standards of hygiene and sanitation. In many developing countries, improved hygiene standards and socio-economic conditions have led 
to a reduction in exposure to HAV in childhood and hence large non-immune adult population in the community. This leads to a shift or transition from asymptomatic childhood infections to an increased incidence of symptomatic or clinical disease in adults [8]. The persistence of circulating HAV may lead to hepatitis A outbreaks in susceptible non-immune adult population $[8,9]$.

\subsection{Disease severity}

HAV causes an acute self-limited illness. The vast majority of hepatitis A patients make a full recovery and fatality rate is low. The estimated mortality rate is $0.1 \%$ for children less than 15 years old, $0.3 \%$ for adults ages 15 to 39 , and $2.1 \%$ for adults ages 40 and old [10,11]. HAV does not lead to chronic hepatitis or a carrier state and only rarely leads to fulminant hepatic failure (FHF) [12]. FHF occurs during the first 4-6 weeks of illness which is characterized by sudden onset of high fever, marked abdominal pain, vomiting and jaundice followed by development of hepatic encephalopathy associated with deep coma and seizures [13,14]. Mortality is highly correlated with increasing age, survival being rare over the age 45 years [15]. The acute HAV super infection with chronic liver disease is also associated with severity and high mortality $[16,17]$.

\subsection{Genomic organization}

Like all picornaviral genomes, HAV is divided into three parts: (i) 5' non-coding region (NCR) that comprises approximately $10 \%$ of the genome (ii) single open reading frame (ORF) of 2227 amino acids, that encode all the viral proteins, with regions designated as P1 for capsid proteins, P2 and P3 for non-structural proteins and (iii) short $3^{\prime}$ non-coding region (Fig. 1).

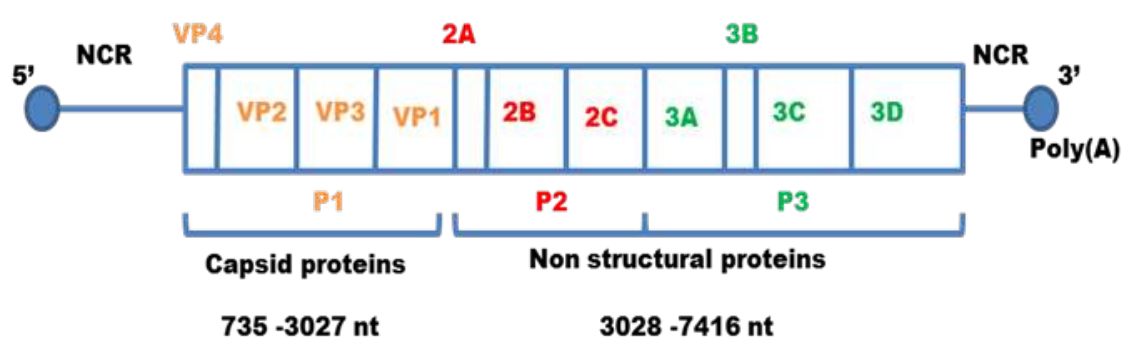

Figure 1. Genomic organization of hepatitis A virus: HAV genome is divided into a $5^{\prime}$ non-coding region $\left(5^{\prime}\right.$ NCR), a giant open reading frame, and a $3^{\prime}$ non-coding region $\left(3^{\prime} N C R\right)$. The coding region is subdivided into regions $\mathrm{P} 1, \mathrm{P} 2$ and P3. (Adapted from: Ref. 20)

HAV RNA genomes lack the cap assembly found at the 5' end of mRNA species that normally guides the ribosomal complex to the translation start site [18]. Instead, an internal ribosome entry site (IRES) formed by the 5'NCR functions to initiate translations in HAV including other picornaviruses $[19,20]$. However, unlike other picornavirus IRESes, the HAV IRES requires an intact eukaryotic initiation factor $4 \mathrm{G}$ for its optimal activity [20]. Several other host proteins 
are found to be associated with synthetic RNAs representing segments of the $5^{\prime}$ NCR [21]. The viral capsid protein (P1) is further divided into VP4, VP2, VP3 and VP1 regions. The nonstructural $\mathrm{P} 2$ and $\mathrm{P} 3$ polyproteins are divided into 2A, 2B, 2C and 3A, 3B, 3C, 3D respectively (Fig. 1). HAV polyprotein is processed into precursor intermediates and mature proteins by the proteolytic activities of encoded viral proteins. HAV 2A, 2B, 2C protein encodes 45, 251 and 335 amino acids respectively. The $2 \mathrm{~A}$ and $3 \mathrm{C}$ are identified as processing enzyme in hepatitis $\mathrm{A}$ virus. The translated $2 \mathrm{~A}$ regions function as intermediary, partially located on the surface (VP1) and some are assembled inside the virion [20]. Both 2B and 2C proteins play an important role in the replication of the viral RNA. P3 polyproteins encodes $3 \mathrm{~A}, 3 \mathrm{~B}, 3 \mathrm{C}$ and $3 \mathrm{D}$ proteins with 74, 23, 219 and 489 amino acids respectively. $3 C$ protein acts as sole protease for HAV protein processing, while 3D is the RNA dependent RNA polymerase [22].

\subsection{HAV genotypes and geographic distribution}

Genetic heterogeneity of hepatitis $\mathrm{A}$ has been revealed by sequencing different genome regions, including VP3 carboxyl terminus, the VP1 amino terminus and the VP1/2A junction [23-25] (Fig. 2). The VP3 C-terminal region is relatively conserved, the VP1 amino acid terminus presents an intermediate variability, while VP1/2A junction is more variable and is used to distinguish one strain from another [25]. The genetic variability observed within the putative VP1/2A junction (168 nucleotides) initially defined seven (I-VII) genotypes [26-29]. However, recently new classification of HAV has been done based on the complete sequences of the 900 nucleotides of VP1 region [30] (Fig. 2).

900 nucleotides

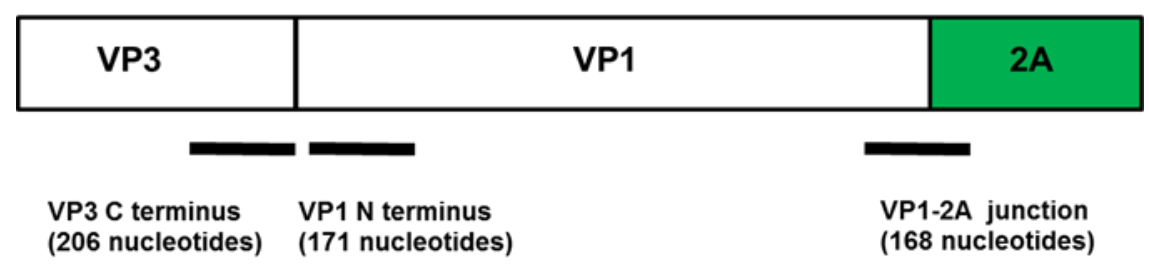

Figure 2. The genomic organization of VP3 C-terminal, the VP1 amino acid terminal and VP1/2A junction region of hepatitis A virus. The complete sequence of the 900 nucleotides of the VP1 gene has been used for new classification of HAV. (Adapted from: Ref. 30)

The phylogenetic analyses of VP1 sequences identified six genotypes (I-VI) that differ among themselves $15-25 \%$. Three isolated from humans (I-III) and three from a simian origin (IV-VI). The genotypes I, II and III were further subdivided into sub-genotypes A and B, which differ in approximately $7.5 \%$ of base positions. The worldwide genotype distribution showed genotype I and III comprise the vast majority of human strains within the studied population (Fig. 3). Sub-genotype IA comprises the majority of the human strains studied and constitutes 
major virus population in North and South America, China, Japan, Russia and Thailand. The sub-genotype IB contains strains from Jordan, North Africa, Australia, Europe, Japan and South America. Most of the remaining human HAV strains segregate into genotype III that is further divided into two sub-genotypes, IIIA, and IIIB [23,27,29]. The sub-genotype IIIA have been subsequently identified in specimens collected from humans with hepatitis A in India, Sri Lanka, Nepal, Malaysia, Sweden and the U.S.A [26,31].The IIIB sub-genotype is responsible for cases of HAV infection in Japan and Denmark.

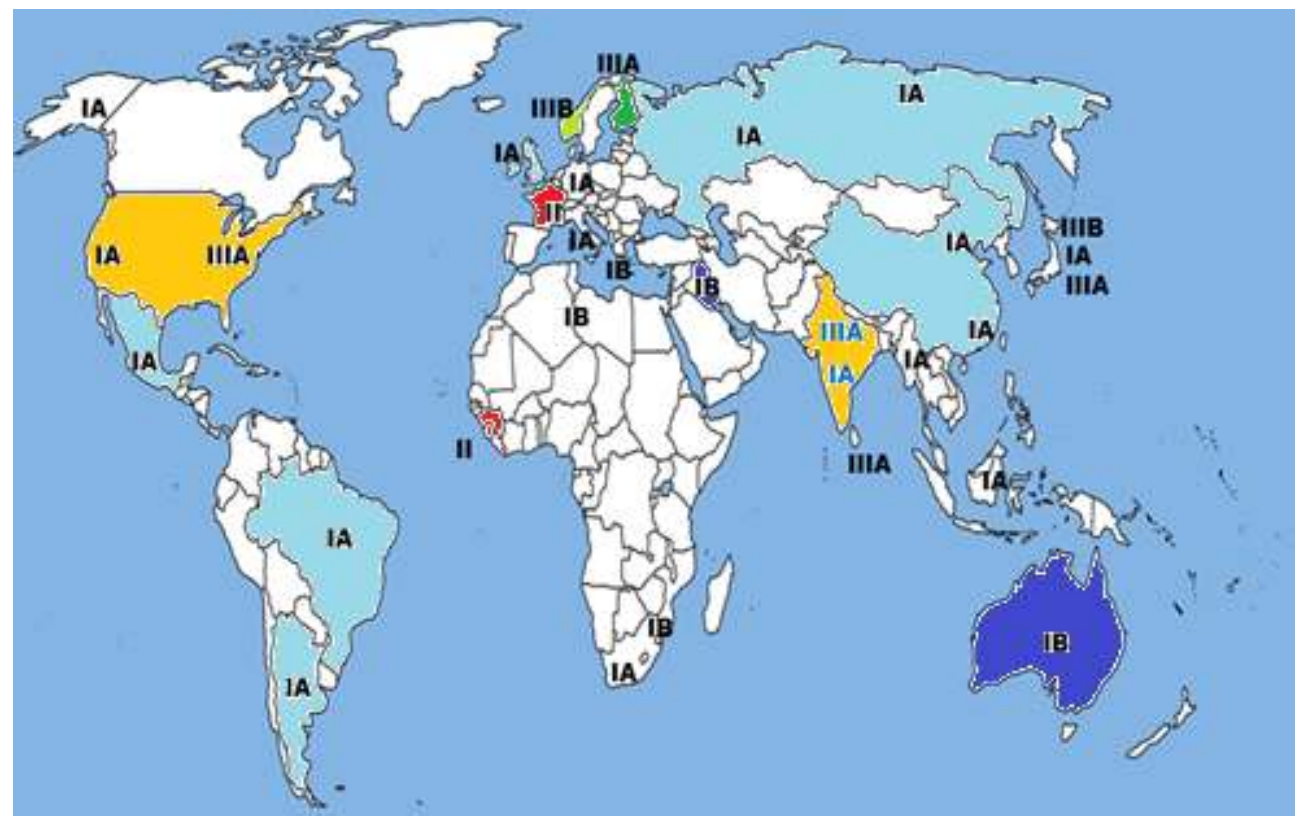

Figure 3. Worldwide distribution of hepatitis A virus genotype(s) according to the VP3 carboxyl terminus, the VP1 amino terminus and the VP1/P2A junction. (Adapted from: Ref. 4, 23, 26, 27, 29, 30 \& 31)

\subsection{Effect of HAV genotype on disease severity}

Although, HAV causes an acute self-limited illness but rarely, it also involved in severe course such as fulminant hepatitis, relapsing hepatitis, prolonged and cholestatic hepatitis. The question arises, if genetic heterogeneity/ genotypes play any role in self-limiting or severe course of the disease. There are contradictory reports regarding the role of HAV genotype in disease severity. Fujiwara et al., [32], reported an association between the severity of hepatitis A and nucleotide variations in the central portion of the 5 ' NCR of Japanese HAV RNA. Similar study from South Korea reported no association between 5'NCR sequence variations and disease severity [33]. Several other studies also reported no association between genotype or nucleotide changes with disease severity [34-37]. Recently, a comparative analysis of disease severity between genotype $1 \mathrm{~A}$ and IIIA revealed that the patients with genotype IIIA were 
older and had high alanine aminotransferase (ALT) levels, prolonged prothrombin times and lower serum albumin level [38]. Another study indicated that co-infection of 2 sub-genotypes (1a and $1 b$ ) in a patient with acute hepatitis accounted for the prolonged and severe course of illness [39]. Therefore, additional studies are needed to define the precise role of viral genotypes in the severity of hepatitis A.

\subsection{HAV genotype and antiviral treatment response}

Since most of the cases are self-limiting, acute HAV does not require antiviral therapy in immunocompetent patients related to any genotype. The immunosuppressed patients should be recommended ribavirin, so that these patients should not progressed to cirrhosis. Liver transplantation is the only treatment option for patients with fulminant hepatic failure due to HAV. Since hepatitis A exists as a single serotype and human is the only host, it is possible to eradicate by selective vaccination against individuals who are susceptible and sero-negative for HAV-IgM.

\section{Hepatitis B virus}

HBV is a member of the Hepadnaviridae family and is known to be one of the smallest human DNA virus [40,41]. HBV infection is very common worldwide with more than 350 million (5\%) of the world's population is chronic carriers [42-44]. Most acute infections with hepatitis B virus are self-limited with clearance of virus and development of immunity [45,46]. However, an estimated $5 \%$ to $10 \%$ of adults and $85 \%$ to $95 \%$ of children develop chronic hepatitis B virus infection [47].The prevalence of HBV infection varies throughout the world [44,48]. The prevalence of HBV infection in Asia and Africa is high (8\%), with perinatal and early childhood transmission resulting in a high rate of chronicity $[44,46,48]$. The Mediterranean and Eastern Europe have an intermediate (3-5\%) endemicity and maintained mainly through sexual, household, nosocomial and perinatal transmission [44,46,48]. The prevalence of chronic infection in some areas of Europe, North America and Australia is less than 1\% and disease is mostly transmitted via sexual contact or through intravenous drug use [46].

\subsection{Disease severity}

Chronic hepatitis B (CHB) is responsible for 1 million deaths per year globally [49]. It is a major cause of cirrhosis of the liver and hepatocellular carcinoma (HCC) worldwide [50,51].The integrity of the host immunological system, viral replication and probably the genetic heterogeneity (genotypes and mutations) of the (HBV) play an important role in the determination of the natural history $[52,53]$. However, the high morbidity and mortality associated with chronic HBV results in a substantial medical and economic burden on healthcare systems, marking HBV as an international health problem $[52,53]$. 


\subsection{Genomic organization}

$\mathrm{HBV}$ is an enveloped virus (42-47 $\mathrm{nm}$ in diameter) with an inner icosahedral nucleocapsid containing DNA genome [54]. The viral genome is approximately about $3.2 \mathrm{~kb}$ long, partially double-stranded relaxed circular (rc-dsDNA) structure and covalently bond to the viral encoded DNA polymerase [50,55-57]. The HBV genome has a highly compact coding structure consisting of four overlapping reading frames (ORF) designated as $\mathrm{P}$ (polymerase), $\mathrm{S}$ (surface/ envelope), Pre-C/C (core) and X (HBx protein) (Fig. 4) [55,56,58]. The polymerase ORF is the largest and it overlaps the $\mathrm{X}$, the core and the pre-S/S. The pre-S/S ORF has 3 initiation codons encoding the small hepatitis B surface protein (SHBs), middle hepatitis B surface protein (preS2 $+\mathrm{S}$ ) and large hepatitis B surface protein(pre-S1 + pre-S2 +S) proteins. C ORF encodes the core protein $(\mathrm{HBcAg})$ and pre-core or e' antigen ( $\mathrm{HBeAg})$ and it contains an N-terminal extension of 29 amino acids [55,56,58,59].

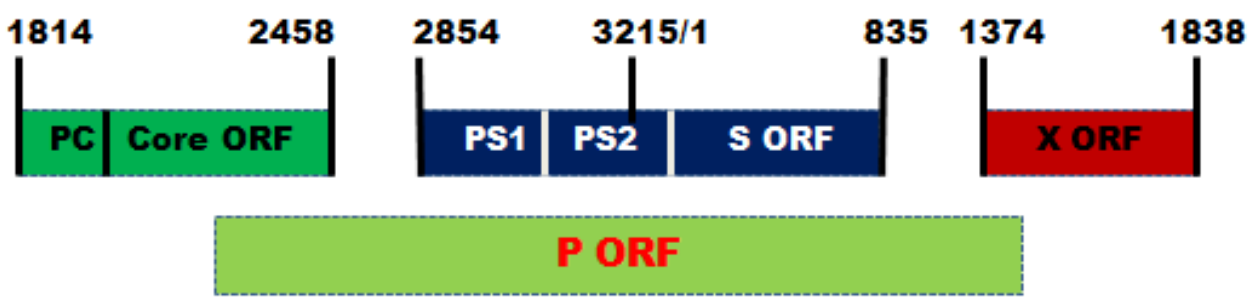

Figure 4. The schematic representation of HBV genome. The circular HBV genome is presented as a linear form. The coding regions for e/core, surface, polymerase and $X$ proteins are designated as $\mathrm{PC} / \mathrm{C}, \mathrm{S}, \mathrm{P}$ and $\mathrm{X}$ respectively. (Adapted from: Ref. 59, 55 \& 58)

\subsection{HBV genotypes and geographic distribution}

HBV can be classified into 10 genotypes A to J, based on the comparison of complete HBV genomes [60-64]. These genotypes are based on a divergence of $8 \%$ or more in the complete nucleotide sequence of the entire viral genome [61-64]. There are numerous subgenotypes (currently approximately 24) has been identified based on genetic diversity of HBV $[65,66]$. These subgenotypes were differentiated by a sequence divergence by at least $4 \%[65,66]$. Since genotypic variation of $\mathrm{HBV}$ is reflected in a partial sequence of $\mathrm{HBV}$, therefore genotyping of $\mathrm{HBV}$ is possible without determining the entire genomic sequence $[60,67,68]$. As shown in Fig. 5 , the $S$ gene is more conserved than the pre-S region, therefore the analysis of the $S$ gene is much more suitable for genotyping. Recently, a fragment of $1306 \mathrm{bp}$ partially comprising HBsAg and polymerase coding regions(S/POL) has also been used for genotyping (Fig. 5) [69]. Several methods have been employed to genotype hepatitis B virus; (a) Direct sequencing [70] (b) Restriction fragment length polymorphism (RFLP) [71] (c) Line Probe Assay (LiPA) [72] (d) Genotype specific PCR [73]. 


\section{Highly conserved}
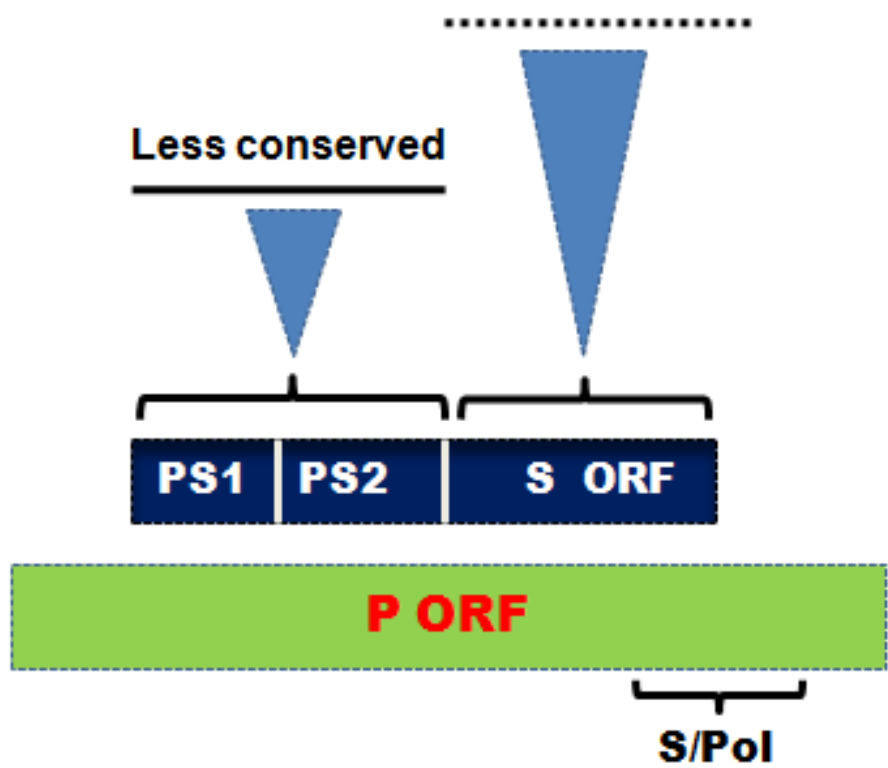

Figure 5. Common genotyping region of HBV genome. The most suitable region for genotyping is $\mathrm{S}$ and S/Pol indicated by dotted line (...). (Adapted from: Ref. 60, 67, 68 \& 69)

The distribution of HBV genotypes varies across different geographical regions (Fig. 6). HBV Genotype A is most commonly found in the Americas, Africa, India and Western Europe [74, 75]. Genotype B is most common in Asia including Japan, Taiwan, Indonesia, China and Vietnam [76-79]. Genotype C is predominant in East Asia and countries of the Pacific Rim [68], while genotype D most commonly found in the Mediterranean, India, Middle East [75,80-82]. HBV genotype $\mathrm{E}$ is mainly identified in sub-Saharan Africa, genotype $\mathrm{F}$ in South and Central America as well as Alaska, and genotype G in Central and North America as well as Europe [83-85]. The most recent HBV genotype identified, genotype $H$, has been found in the United States, Mexico and Central America [86,87]. The genotype $\mathrm{F}$ is the most distantly related genetically of the other HBV genotypes (12.8-15.5\%) [88]. Recently, genotype I, a novel intergenotypic recombination among genotypes A, C and G was isolated in Vietnam and Laos [89]. The newest HBV genotype J, was identified in the Ryukyu island in Japan, and this genotype has a close relationship with gibbon, orangutan and human genotype C [90]. The epidemiology of HBV infection is still shifting and the apparent variations in geographical distribution of genotypes is effect of migration from countries with a high prevalence of HBV infection to countries with a lower prevalence. 


\subsection{Effect of HBV genotypes on disease severity}

There are conflicting report about the role of HBV genotypes and severity of the disease. Recent study from Japan demonstrated that genotype B is associated with slower progression to cirrhosis of the liver compared to genotype $C$ [91]. Another study suggested that acute infection with HBV genotype A increases the risk of progression to chronic infection [79,92]. In China, the patients contracted with HBV subtype $\mathrm{C} 2$ develops chronic infection more often than those infected with subtype B2 $[78,93]$. There are conflicting reports from India; one study found that patients infected with genotype D strains had severe chronic liver disease, while another study could not find genotype D strains to be involved in severity $[75,94]$. Study from East Asia indicated, genotype $\mathrm{C}$ as a predominant genotype in subjects with advanced chronic hepatitis (CH), liver cirrhosis (LC) and hepatocellular carcinoma (HCC) [95]. Taiwanese study demonstrated association of genotype $C$ as a risk factor for HCC than genotype B $[93,96]$. A study from Hong-Kong found that patients infected with genotype B had a higher rate of hepatic decompensation compared to genotype C patients [97]. The HBV patients contracted fulminant hepatitis are more often associated with genotype B [98]. The characteristics of other genotypes (E-J) with disease severity has not been well documented.

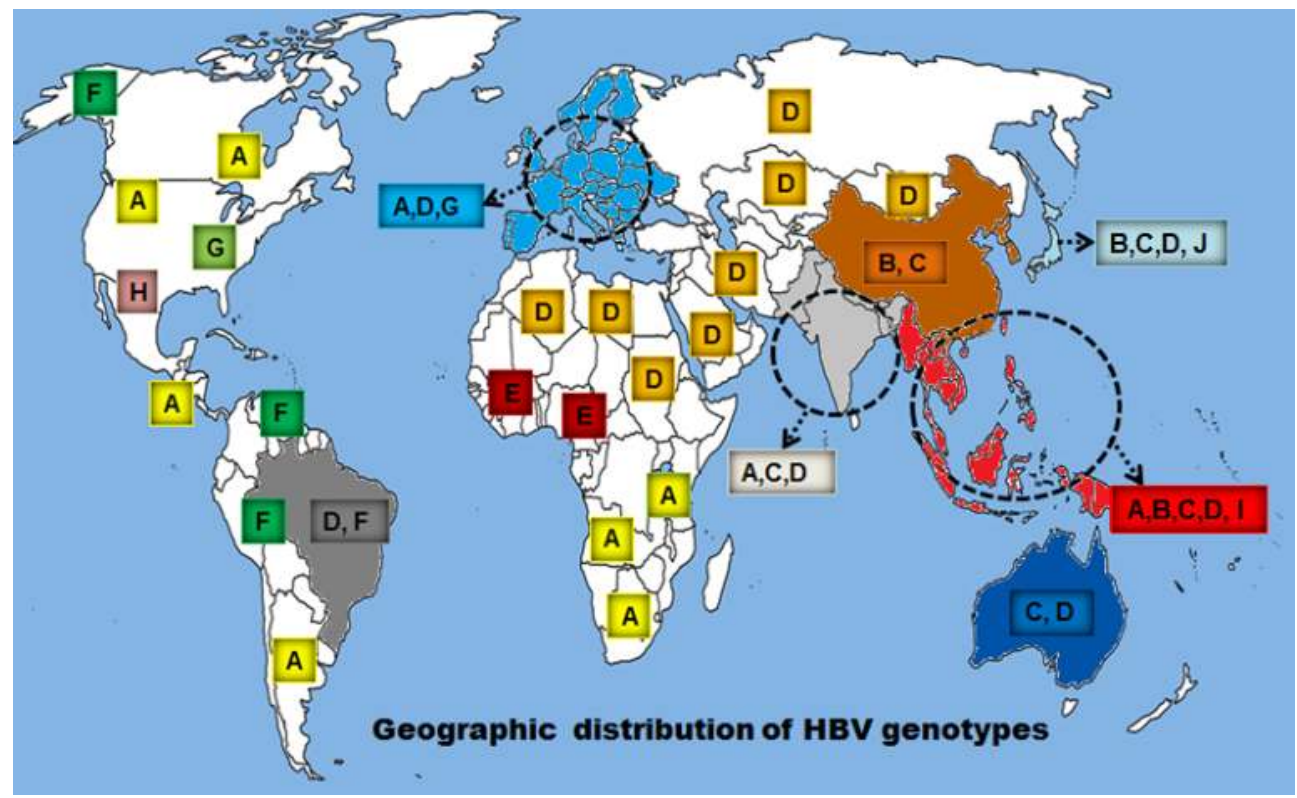

Figure 6. Worldwide geographic distribution of HBV genotypes. (Adapted from: Ref. 68, 74, 75, 77, 79, 81, 82, 83, 84, $86,87,88,89 \& 90)$ 


\subsubsection{Do genotypes influence seroconversion and seroclearance?}

The seroconversion of $\mathrm{e}^{\prime}$ antigen (HBeAg) and seroclearance of surface antigen (HBsAg) are important steps in the natural history of chronic HBV infection [99-102]. Early HBeAg seroconversion typically confers a favorable outcome, while late or absent HBeAg seroconversion after multiple hepatitis flares may accelerate the progression of chronic hepatitis to cirrhosis and hence a poor clinical outcome [99-102]. How these events are influenced by HBV genotypes are subject to a proper understanding and research? Taiwanese study demonstrated that genotype $C$ infection was associated with lower rates of spontaneous HBeAg seroconversion than genotype B [101]. In case of HBsAg seroclearance, the HBV genotypes A and B patients had high frequency compared to genotypes $C$ and D patients $[83,103]$.

\subsubsection{Do genotypes influence frequency of viral mutations?}

Several studies revealed that genotypes do influence the frequency of mutations in HBV genetic make-up. The HBV genotype $C$ infections conferred a higher frequency of basal core promoter (BCP) A1762T/G1764A mutation than genotype B [104,105]. Similarly, patients with genotype D infection had a higher prevalence of BCP A1762T/G1764A mutation than those with genotype A infection [106]. The nucleotide(s) deletion within pre-S region is reported to be associated with genotypic variations. The pre-S deletion was higher in genotype $C$ than genotype B patients [107]. In addition, the presence of pre-S deletion was an independent risk factor associated with disease progression as well as HCC development [108-110].

\subsection{HBV Genotype and antiviral treatment response}

According to different investigators, the nucleotide sequence diversity among different isolates of the virus may play a significant role in response to therapy. The impact of HBV genotype on therapeutic response has been reported in several studies [111,112]. HBV genotype plays a vital role in sustained response (i.e. normalization of serum ALT level and HBeAg seroconversion post treatment) rate. The HBeAg positive patients treated with standard IFN-a, the sustained response rate is significantly better in genotype A and B patients than for genotype C and D [113-116]. Contrary to genotype A-D, patients infected with genotype E-J are rarer and their responses to IFN-based therapy remain largely unknown. In patients treated with nucleos $(t)$ ide analogues, sustained response rate was contradictory in relation to genotype $[117,118]$.

\section{Hepatitis C virus}

$\mathrm{HCV}$ is a small size (55-65 nm), enveloped virus, belong to a member of the family Flaviviridae $[119,120]$. It is mainly transmitted by exposure to contaminated blood or blood products $[121,122]$. This virus is target specific and replicates in the hepatocytes (liver cells). The initial phase of hepatitis $C$ is called the acute infection [123]. The symptoms of acute HCV infection includes fatigue, jaundice, appetite loss, abdominal pain, nausea and vomiting, joint pain, dark 
urine and clay-colored stool [124]. Sixty to seventy percent of people in the acute stage have no symptoms and hence most of HCV cases often goes undiagnosed [123,125]. On the other hand, patients who develop symptoms, the average time period between exposure and symptom onset is 4-12 weeks. Fifteen to twenty percent of acute cases spontaneously clear this virus within 2-12 weeks. However, up to $80 \%$ of people initially infected with HCV do not clear the virus from their bodies, and continue to have liver disease with $55 \%$ develops chronic liver disease [126,127]. Chronic hepatitis $C$ is often silent, most of the times discovered only by routine serological, biochemical and radiological testing [128].

\subsection{Disease severity}

$\mathrm{HCV}$ is a major cause of liver associated disease all over the world with an estimated 3\% of the world's populations are chronically infected $[129,130]$. In some endemic areas, such as the Middle East, North-East Asia and South Africa, the prevalence of HCV infection is as high as $20-30 \%$ [122]. Chronic infection often progresses to liver fibrosis, cirrhosis and hepatocellular carcinoma (HCC) in a substantial number of patients [126-128]. The rate of disease progression is variable and several factors have been identified as important in predicting the outcome of progression such as age at infection, gender, genotype/subtype, viral load, and mode of infection.

\subsection{Genome organization}

$\mathrm{HCV}$ viral genome is positive sense RNA with approximately $9.4 \mathrm{~kb}$ in length containing a poly (A) tail at the 3'end (Fig. 7). The sequence contained a 5'untranslated region (5'ÚTR) of 341 bases and 3'UTR of about 27 bases [120,131, 132]. The HCV genome has a single open reading frame coding for a polyprotein of 3010 amino acids. The poly-protein is cleaved after translation into structural and non-structural proteins necessary for viral replication and virion formation. The structural proteins situated towards the N-terminus of the genome and nonstructural genes located near C-terminal. The 5'UTR is most conserved region of HCV and is pivotal for the initiation of translation and ribosomal binding [133-135]. The structural genes code for the capsid (core) protein (C) and envelope glycoproteins (E1, E2) [133,134]. The first 27 amino acids of the E2 gene constitute the hyper-variable region 1 (HVR1) of the genome and seems to be involved in virus evasion of the immune system and disease progression [136]. The non-structural genes code for a protease (NS2, NS3) and its cofactor (NS4A), a helicase (NS3), a protein of unknown function (NS4B), a phosphoprotein (NS5A), and an RNAdependent RNA polymerase (NS5B) [137].

The virus replicates in the cytoplasm using an RNA-dependent RNA polymerase that lacks general proofreading ability [138]. This error-prone RNA polymerase is responsible for the genetic variability exhibited by $\mathrm{HCV}$ isolates and high spontaneous nucleotide substitution rate with a frequency of $10^{-2}$ to $10^{-3}$ substitutions per nucleotide site per year [139]. HCV circulates as a heterogeneous population or quasispecies which differ by $1-5 \%$ in nucleotide sequence diversity [140]. Quasispecies permits rapid adaptability of the virus in the event of environmental changes and a clever strategy utilized by the virus to escape selective forces such as nucleotide antiviral agents or the immune system $[139,140]$. 


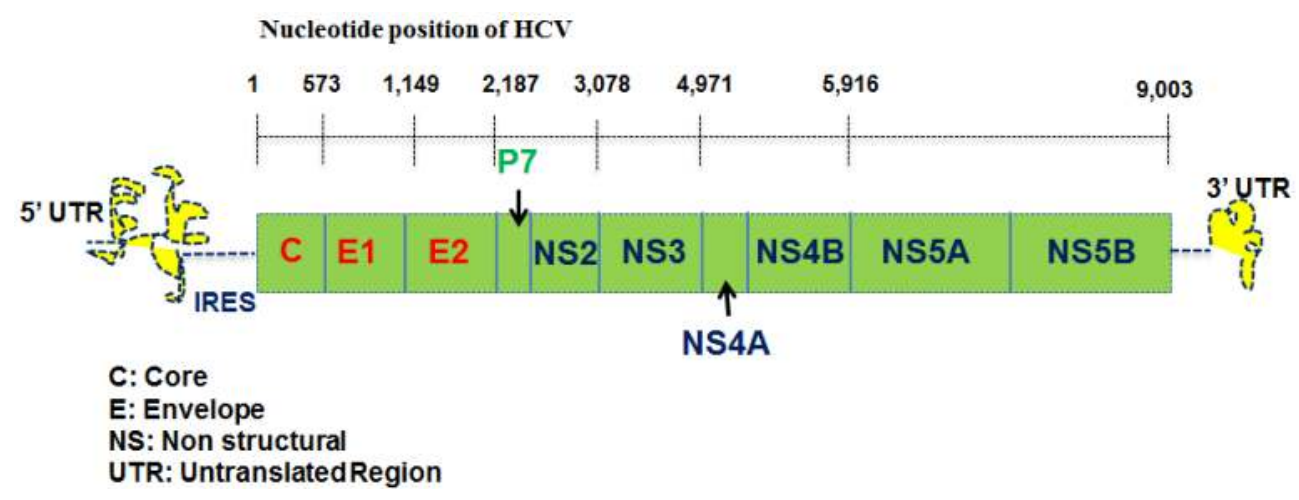

Figure 7. Genomic organization of HCV: The HCV genome contains a single open reading frame (ORF). The genes for structural proteins (C, E1, E2, P7) are situated towards the N-terminus of the ORF. Genes coding for proteins necessary for viral replication are found towards the C-terminus of the ORF. (Adapted from: Ref. 120, 131 \& 133)

\subsection{HCV genotypes and geographic distribution}

The HCV genotype has been determined primarily based on analysis of partial genome sequences. Investigators have typically used sequence analysis of NS5B, core, E1, and 5'UTRs for HCV genotyping (Fig. 8). The most widely accepted classification system of HCV genotyping is that of Simmonds et al. 1993 [137]. This system is based on the sequence variability of the 222 base pairs of the NS5B region and it divides HCV isolates into six phylogenetically distinct groups, and more than 80 subtypes. However, following the description of the new genotypes 7-11, Robertson et al., 1998, measured that it was more accurate for the genotypes $7,8,9$ and 11 to be assigned as subtypes of genotype 6 and the genotype 10 to be a subtype of the genotype 3 [141]. Several methods have been employed to genotype hepatitis C virus; (a) Direct sequencing [140] (b) Restriction fragment length polymorphism (RFLP) [142] (c) Line Probe Assay (LiPA) [143] (d) Genotype specific PCR [144].
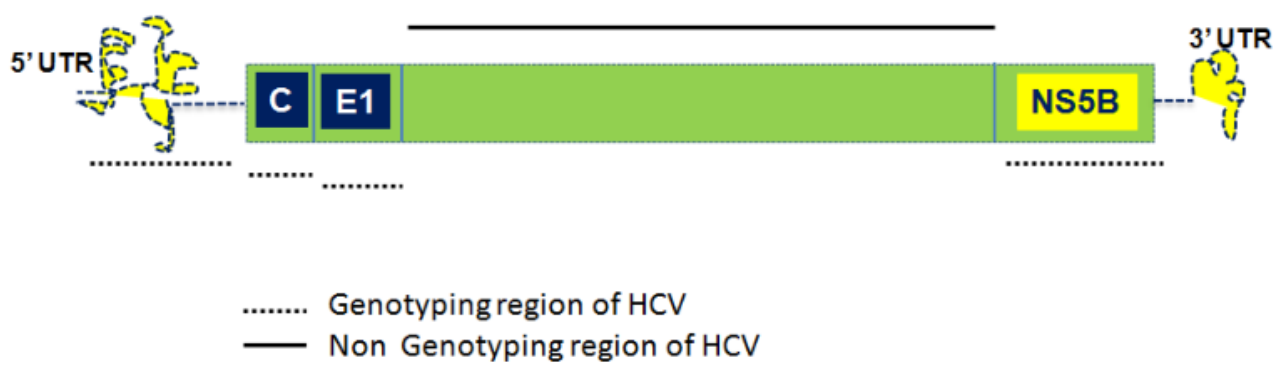

Figure 8. Genotyping region of HCV: The most suitable region for genotyping are $5^{\prime}$ UTR, Core (C), E1 and NS5B indicated by dotted (...) line. (Adapted from: Ref. 138, 140, 141, 146 \& 147) 
At least 6 major genotypes of HCV, each comprising multiple subtypes have been identified worldwide [138,145-147]. Each genotype is separated by sequence divergence in the entire genome exceeding $30 \%$. Substantial regional differences appear to exist in the distribution of HCV genotypes (Fig. 9). Although HCV genotypes 1, 2, and 3 appear to have a worldwide distribution, their relative prevalence varies from one geographic area to another [145]. HCV subtypes $1 \mathrm{a}$ and $1 \mathrm{~b}$ are the most common genotypes in the United States [145]. These subtypes also are predominant in Europe [148]. In Japan, subtype $1 \mathrm{~b}$ is responsible for up to $73 \%$ of cases of HCV infection [149]. Although HCV subtypes $2 \mathrm{a}$ and $2 \mathrm{~b}$ are relatively common in North America, Europe, and Japan, subtype 2c commonly found in northern Italy [146]. HCV genotype $3 \mathrm{a}$ is particularly prevalent in intravenous drug abusers in Europe and the United States [150]. HCV genotype 4 appears to be prevalent in North Africa and the Middle East [151, 152], type 5 mainly in South Africa and type 6 principally in Hong Kong and Southeast Asia $[137,153]$. Mixed genotype infections from a major and a minor HCV population accounts for $4-17 \%$ of HCV patients [154].

\subsection{Effect of genotype on disease severity}

In recent years, substantial evidence has emerged indicating the role of HCV genotypes in disease severity and sensitivity to the antiviral therapy $[140,146]$. Importantly, patients infected with any of the 6 genotype can develop advanced liver disease, including cirrhosis and HCC. However, some genotypes appear to be more severe compared to the other. For example, Chronic HCV patients infected with genotype $1 \mathrm{~b}$ is reported to be associated with a more severe liver disease and a more aggressive course compared to genotype 2 (146,155-157]. HCV genotype $1 \mathrm{~b}$ has also been reported to be associated with the development of advanced liver disease including cirrhosis and hepatocellular carcinoma (HCC) compared to other genotypes $(157,158]$. However, other investigators failed to arrive at the same conclusions for genotype $1 \mathrm{~b}$ and therefore further studies are required to elucidate any role of HCV genotype in disease progression or severity [159-162]. A study from India, indicate that most of the chronic hepatitis patients related to genotype 3 is associated with significant steatosis (accumulation of fat within hepatocytes) and fibrosis [163]. Another study report steatosis regardless of genotypes, but resolution of viral infection from genotype 3 a patients is associated with disappearance of steatosis and hence genotype $3 a$ and steatosis are interlinked [164]. According to latest statistics $15 \%$ of Egyptians are infected with HCV and most of these patients have genotype $4[165,166]$. Genotype 4 has also been associated with a severe disease and increased development of HCC [165]. HCV Genotype 5 is associated with higher mean age compared to other HCV genotype infection [167]. Report from Hong Kong suggested prominence of genotype 6 in patients with thalassemia major and intravenous drug abusers [168].

\subsection{HCV genotype and antiviral treatment response}

The main objective of therapy administered to patients with chronic hepatitis $C$ is to achieve a Sustained Virological Response (SVR). SVR is characterized by the clearance of serum HCV RNA at the end of therapy and maintained throughout the 6-month follow up period after completion of treatment [169]. The current treatment for HCV infection is two daily doses of 


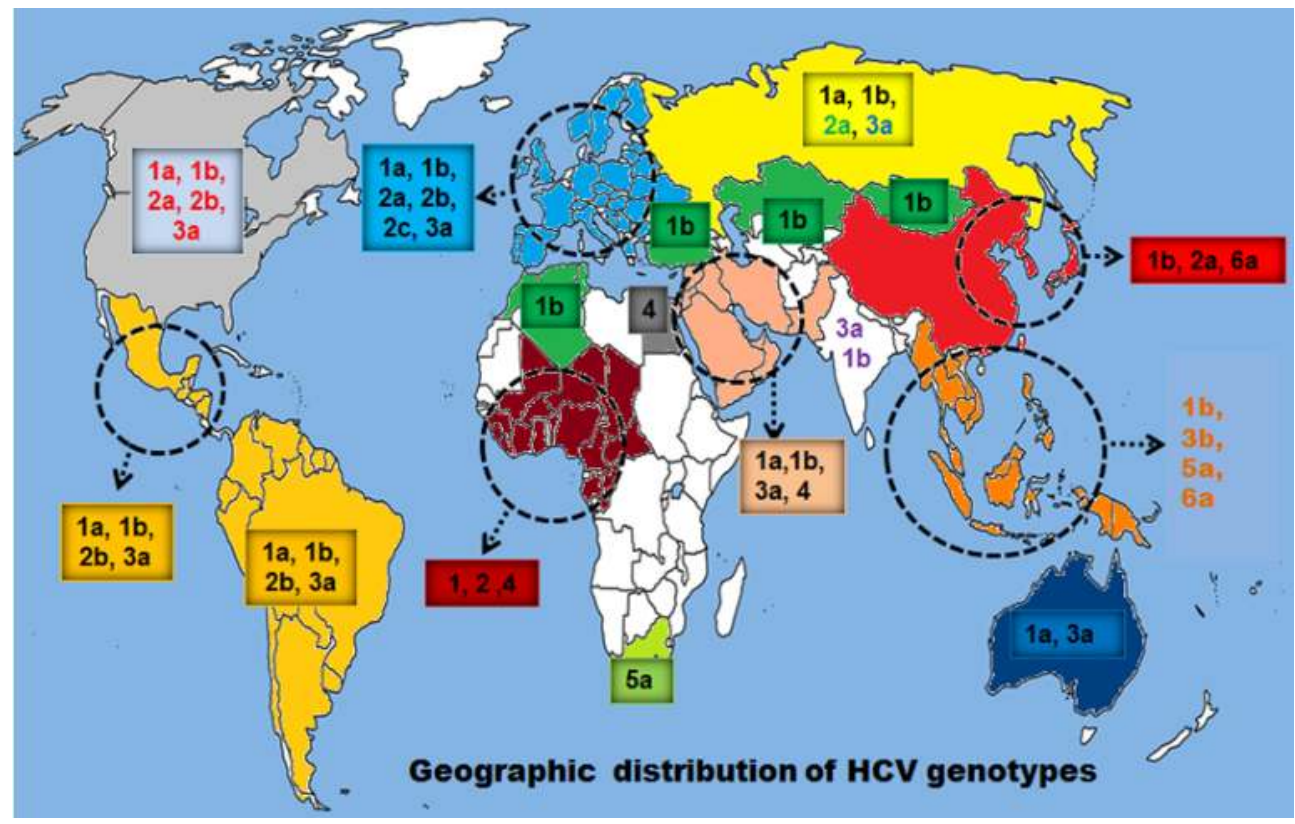

Figure 9. Worldwide geographic distribution of HCV genotypes. (Adapted from: Ref. 138,146,147 \& 152)

ribavirin (non-specific anti-viral agent) combined with a weekly injection of interferon- $\alpha$ (standard or pegylated) [170]. The recommended treatment length depends on the virus genotype. Patients with genotypes 2 and 3 are almost three times more likely than patients with genotype 1 to respond to the combination of alpha interferon and ribavirin therapy [129, 164, 171, 172]. Notably, patients with genotype 2 and 3, a 24 week course of combination treatment is adequate, whereas a 48 week course is recommended for genotype 1 [172]. Although, the response of combination therapy against genotype 2 and 3 is better, still there are moderately high percentage of non-responders. The re-treatment response involving combination therapy in non-responders are still better in genotype 2 and 3 (50-60\% SVR) compare to genotype 1 (14\%) [173]. Genotype 4 presents advance liver disease in patients, and response to Interferon-Ribavirin combination therapy is moderate with $\sim 60 \%$ SVR after 48 weeks treatment [174]. Similarly, among genotype 5 patients, the response rate achieved is more than $60 \%$ SVR, when treated with Interferon-Ribavirin combination therapy for 48 weeks [175]. HCV genotype 6 responds better to Interferon-Ribavirin combination therapy compare to genotype 1 with treatment duration of 48 weeks [176].

\section{Hepatitis D virus}

HDV was first discovered in 1977 among a group of patients infected with hepatitis B virus [177]. HDV depends on the HBV to provide hepatitis B surface antigen (HBsAg) for virion 
assembly and propagation [178]. There are approximately 350 million chronic HBV carriers of the virus, according to the available data 5\% (15 million) of these HBV carriers are infected with HDV $[179,180]$. HDV is highly endemic in Mediterranean countries, Middle East, Central Africa, and northern parts of South America [181]. In contrast, in industrialized countries, its prevalence is low and its transmission is often associated with intravenous drug use [182]. HDV is transmitted through blood and body fluids, quite similar to that of HBV [183]. Hepatitis D symptoms are identical to other viral hepatitis diseases and include jaundice, fever, malaise, dark urine and nausea [183].

\subsection{Disease severity}

HDV propagates in human hepatocytes as its natural host but only in presence of hepatitis B virus, causing severe acute, fulminant or chronic hepatitis leading to liver cirrhosis $[179,184$, 185]. HDV infection can occur either as a co-infection with HBV or as a superinfection in patients with chronic HBV infection [179]. The individuals with HBV-HDV co-infection resulted in more severe acute disease and a higher risk of fulminant hepatitis than HBV alone (1983). Only $2 \%$ of co-infected patients resulted in chronic infection [186]. Super infection with HDV in HBV chronic carriers leads to higher incidence of cirrhosis and hepatocellular carcinoma [187]. A factor that may influence the course of disease is the genetic heterogeneity of HDV prevalent in different geographical areas [188].

\subsection{Genome organization}

The HDV virion is a spherical particle of about 36-nm in diameter, which contains an envelope (HBsAg) and a nucleocapsid containing an RNA genome in complex with HDAg [189-191]. HDV particles consist of a negative sense, circular, single-strand RNA genome, approximately $1.7 \mathrm{~kb}$ in length. HDV anti-genome contains a unique open reading frame that encodes the small (sHD) and large hepatitis delta (LHD) proteins. The sHD and LHD correspond respectively to the small-p24 and the large-p27 hepatitis delta proteins [192]. The LHD amino acid sequence is identical to sHD except with the extension of 19 to 20 amino acids at carboxyterminal end [192, 193]. sHD is required for viral replication and might promote RNA polymerase II elongation of nascent HDV RNA, while LHD inhibits HDV RNA replication and is required for HDV RNA packaging with the HBV envelope protein [194].

\subsection{HDV genotypes and geographic distribution}

To date researchers have identified 8 major clades or genotypes of hepatitis delta virus based on phylogenetic analysis and are labeled as HDV-1 to HDV-8 [195]. These genotypes are mostly defined based on the analysis of 357 nucleotide semi-conserved region of HDV genome $[187,196,197]$ (Fig. 10). The sequence differences among these genotypes are significant; there is a divergence of $40 \%$ in nucleotide sequence and $35 \%$ in amino acid sequence of HDAg. Distribution of genotype 1 is ubiquitous which includes European, North American, African, and some Asian isolates [187,196-199]. Genotype 2 has been found in Japan, Taiwan and Yakoutia (Russia) [200]. Genotype 3 has been found exclusively in Central and South 
America [187]. Genotype 4 was mostly prevalent in Japan and Taiwan [200,201]. Genotype 5-8 has been exclusively found in Africa [195] (Fig. 11).

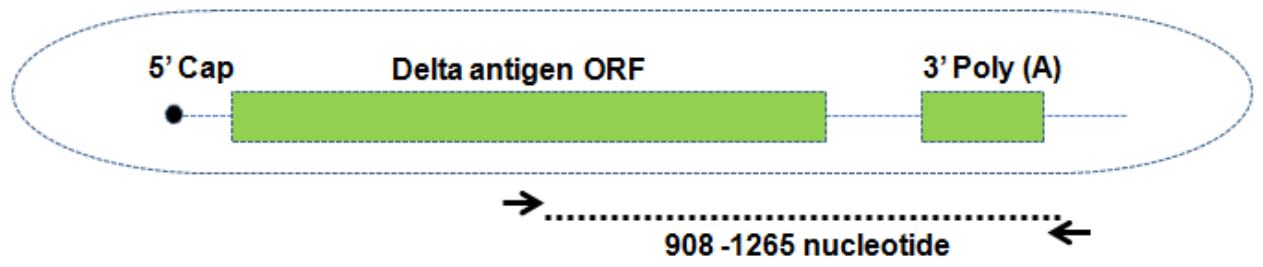

...... Genotyping region of HDV

Figure 10. Genotyping region of HDV: The most widely used region for genotyping is spanning 908-1265 nucleotide, which encodes the second half of HDAg protein indicated by dotted line (...). (Adapted from: Ref. 190)

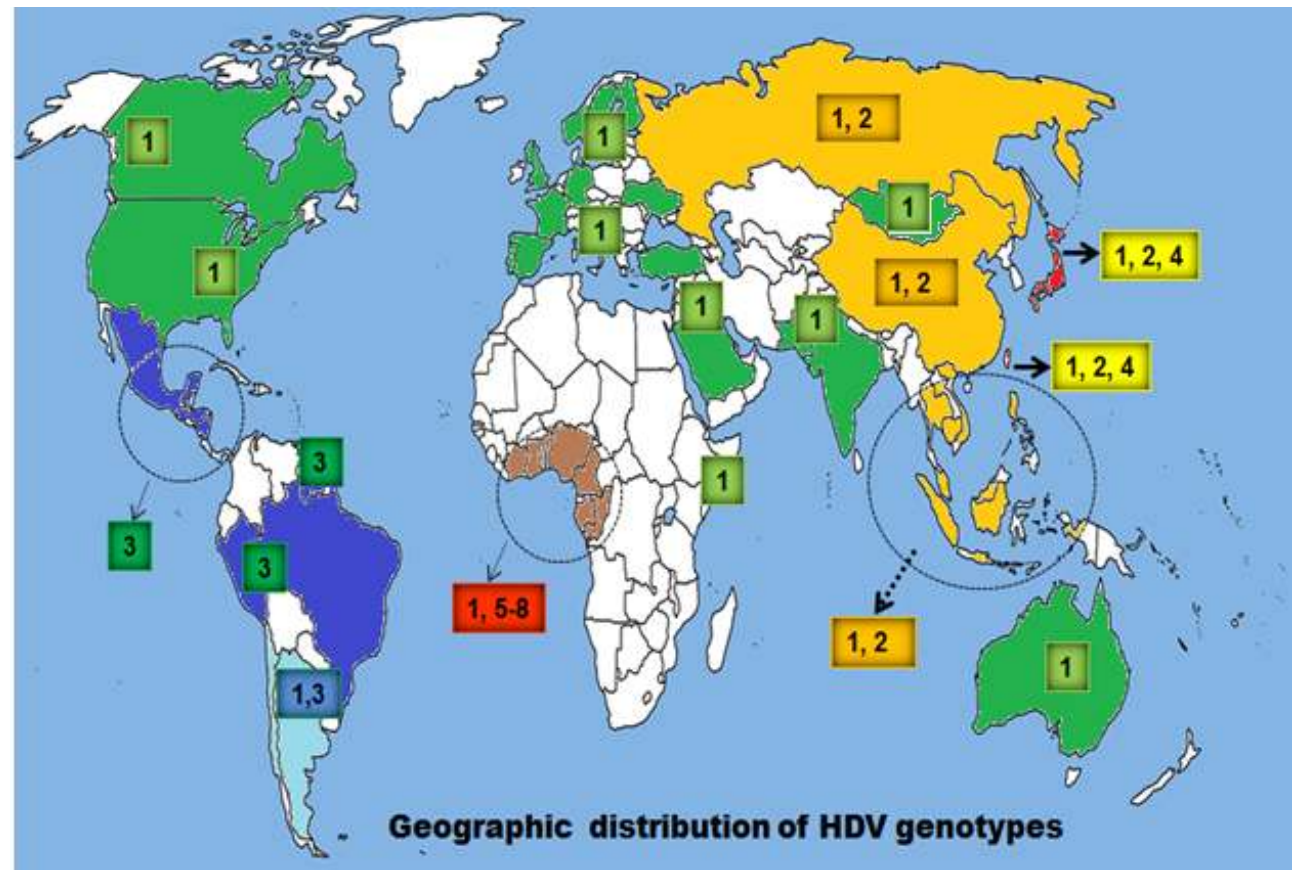

Figure 11. Worldwide geographic distribution of HDV. (Adapted from: Ref. 181 \& 195) 


\subsection{Effect of genotype on disease severity}

The genetic variant of hepatitis D virus along with geographical location and transmission route have been identified as important determinants of disease severity [202,203]. At one geographic location genotype 1 has been associated with fulminant hepatitis and hepatocellular carcinoma [196], while in other locality the same genotype have a mild clinical course $[197,199]$. The diversity observed among genotype HDV-2 has been associated with a less aggressive course, lower ALT values and HDV RNA levels than genotype HDV-1[196,204]. Genotype HDV-3 is endemic in northern South America and is associated with a severe clinical course [184]. Genotype HDV-4 (previously labeled HDV-IIb) also showed variable severity depending upon the geographic location [200,201,205]. Genotype HDV (5-8), mostly observed in African patients, most patients suffered from active chronic hepatitis or cirrhosis [181,195].

\subsection{HDV Genotype and antiviral treatment response}

There is no specific treatment for HDV infection. Treatment of chronic delta hepatitis is not very effective using long-term administration of high doses of interferon-alpha [206]. It is not known whether some HDV genotypes might be more susceptible to therapy than others. Although, there is no specific vaccine for HDV but vaccination of persons at high risk of acquiring HBV will prevent the acquisition of HDV infection.

\section{Hepatitis E virus}

HEV infection is a significant public health problem in many parts of the world, especially in developing countries [207-209]. It is estimated that about 2 billion people live in areas endemic for HEV [207,208]. HEV is transmitted via the fecal-oral route and target population includes young to middle aged adults [210]. Patients infected with HEV present with nausea, vomiting, anorexia, jaundice, abdominal pain, fever, and hepatomegaly [211]. It causes large outbreaks of acute hepatitis but usually resolves without any therapy [212-214]. The infected individual therefore develops antibodies that protect against future infection.

\subsection{Disease severity}

The clinical presentation of this disease ranges from subclinical to fulminant hepatic failure $[215,216]$. HEV is a major cause of fulminant hepatitis in endemic areas such as India and Bangladesh [216]. Hepatitis $E$ has a mortality rate of $1-4 \%$ in the general population [211]. Increased morbidity and mortality is observed in chronic liver disease patients superinfected with HEV [215]. The endemic area is frequently associated with increased incidence and severity in pregnant women with around $15-20 \%$ mortality rate [217]. More than one-fourth of affected women have obstetric complications, such as premature rupture of membranes and intrauterine growth restriction [218,219]. It is unknown why HEV causes severe disease in pregnant women. 


\subsection{Genome organization}

HEV is a spherical, non-enveloped virus of about $27-34 \mathrm{~nm}$, classified currently as the sole member of the genus Hepevirus in the family Hepeviridae [210,220,221]. Its genome is a single stranded, positive-sense 5 'capped RNA of approximately $7.2 \mathrm{~kb}$ in length $[222,223]$. It contains three overlapping open reading frames (ORF1, ORF2 and ORF3) flanked by short 5' and 3' untranslated regions (UTRs) [224,225] (Fig. 12). The ORF1 encodes a large non-structural protein with several putative functional motifs and domains such as methyltransferase, papain-like cysteine protease (PCP), RNA helicase and RNA dependent RNA polymerase (RdRp) [226]. The ORF2 encodes HEV capsid protein of 660 amino acids and encapsidate the viral RNA genome [227]. The ORF3 of HEV encodes a small protein of 123 amino acids that is essential for viral infectivity in vivo. Both the ORF2 and ORF3 proteins are translated from a single bicistronic subgenomic RNA [228].

\subsection{HEV genotypes and geographic distribution}

Four major genotypes (genotypes 1-4) of mammalian HEV have been identified on the basis of complete genome sequences [229,230]. Recently, partial sequence of HEV conserved region (i.e. ORF1 and ORF2) reflects nucleotide sequence heterogeneity and hence genotyping of HEV is possible without determining the entire genomic sequence [231,232] (Fig. 13). Regions within nucleotides 171-221, 280-310 and 6461-6495 were most conserved and represented the best targets for primer or probe design for genotyping and quantitation [232].

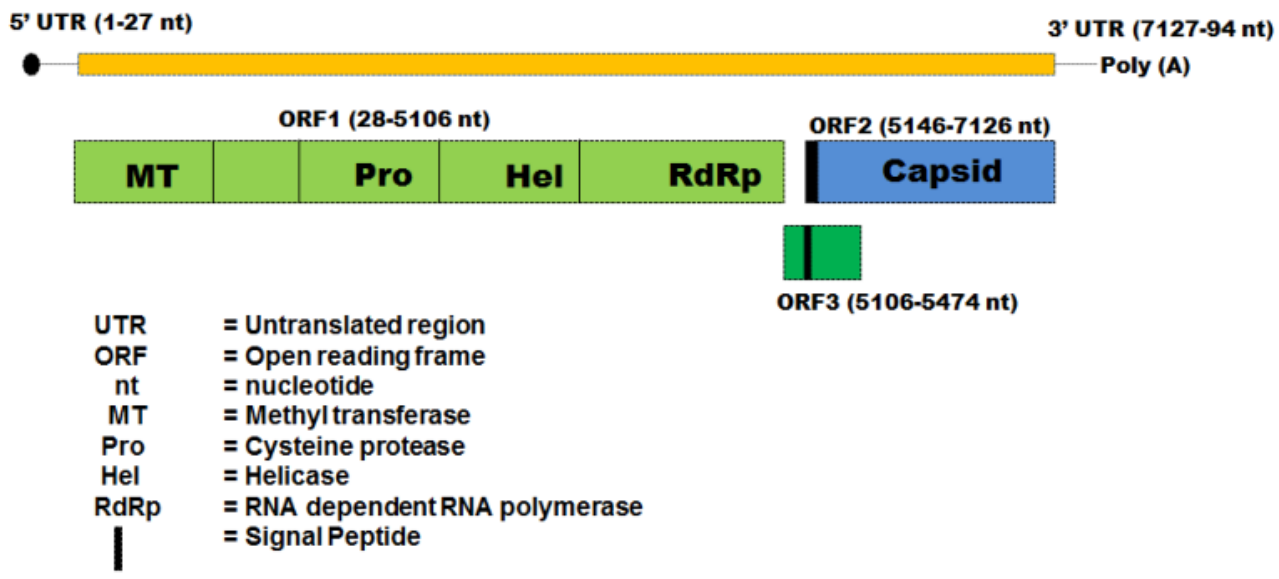

Figure 12. Genomic organization of HEV. HEV RNA is capped at the $5^{\prime}$ untranslated region (UTR) and polyadenylated at the 3' UTR. ORF1 encodes the nonstructural polyprotein; methyltransferase (MeT), papain-like cysteine protease (PCP), RNA helicase (Hel) and RNA dependent RNA polymerase (RdRp). ORF2 encodes the viral capsid protein. ORF3 encodes a small regulatory phosphoprotein.(Adapted from: Ref. 222, 223 \& 224)

Genotype 1 is mostly prevalent in Asia and Africa [230,233,234]. Genotype 2 is found in Central and South America as well in African countries (Fig. 14). Both genotype 1 and 2 outbreaks are 
the result of efficient human-to-human feco-oral transmission mostly in developing countries $[231,234]$. In industrialized countries, HEV genotype 1 infection is rare, therefore its presence there is treated as imported infectious disease [231]. Genotype 3 includes human and swine HEV strains from industrialized countries [235,236]. Finally, genotype 4 includes human and swine HEV strains from Asia, particularly China, Taiwan and Japan [234,237]. HEV strains of genotype 3 and 4 are maintained among animal species and occasionally infect humans probably due to inefficient cross-species transmission [235].

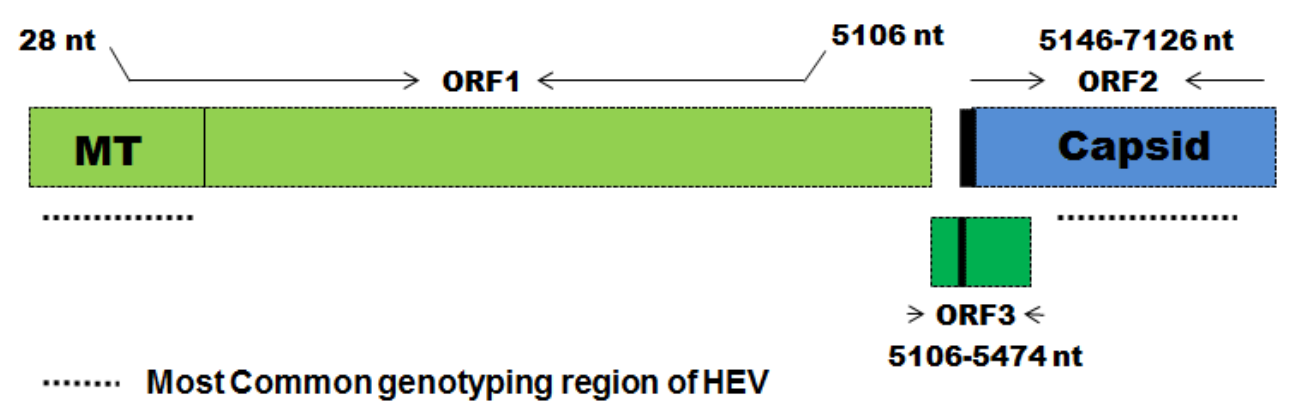

Figure 13. Genotyping region of HEV. The most widely used HEV genomic regions for genotyping are indicated by dotted line (...).

\subsection{Genotype variations and disease severity}

The severity of HEV associated acute hepatitis not only depends on the status of the host's immune system but also on viral factors such as genotypes. Hepatitis outbreaks in developing countries have been caused primarily by HEV genotype 1 . Most of the patients suffering from hepatitis $\mathrm{E}$ caused by genotypes 1 are older children and young adults with mortality rate $1 \%[231,238]$. A study from India reported that the viral load of genotype 1was significantly higher in pregnant patients than in non-pregnant patients, and high viral load might be a reason for severe liver disease in pregnant patients [239]. Genotype 2 is Mexican origin and mostly prevalent in central American and African countries, like genotype 1, it is mostly selflimiting. HEV genotype 3 is prevalent in industrialized nations and is rarely pathogenic. Recently, it has been reported that genotype 4 infected patients showed more severe form of the viral hepatitis than genotype $3[240,241]$.

Most of the patients in this group belong to older age ( $\sim 60$ years) and the mortality rate is relatively high (6-10\%) [231,242]. Japanese study suggested that the silent substitutions of U3148 and C5907 in the genotype 3 and 4 HEV strains are closely associated with the occurrence of fulminant and severe cases and found that C5907 is associated with high HEV load [243]. Thus, the genetic changes in hepatitis E virus genome may affect the effectiveness of virus transmission and hence the severity of HEV-associated hepatitis. Therefore, examination of HEV genotype is considered necessary in order to predict the clinical course and the outcome. 


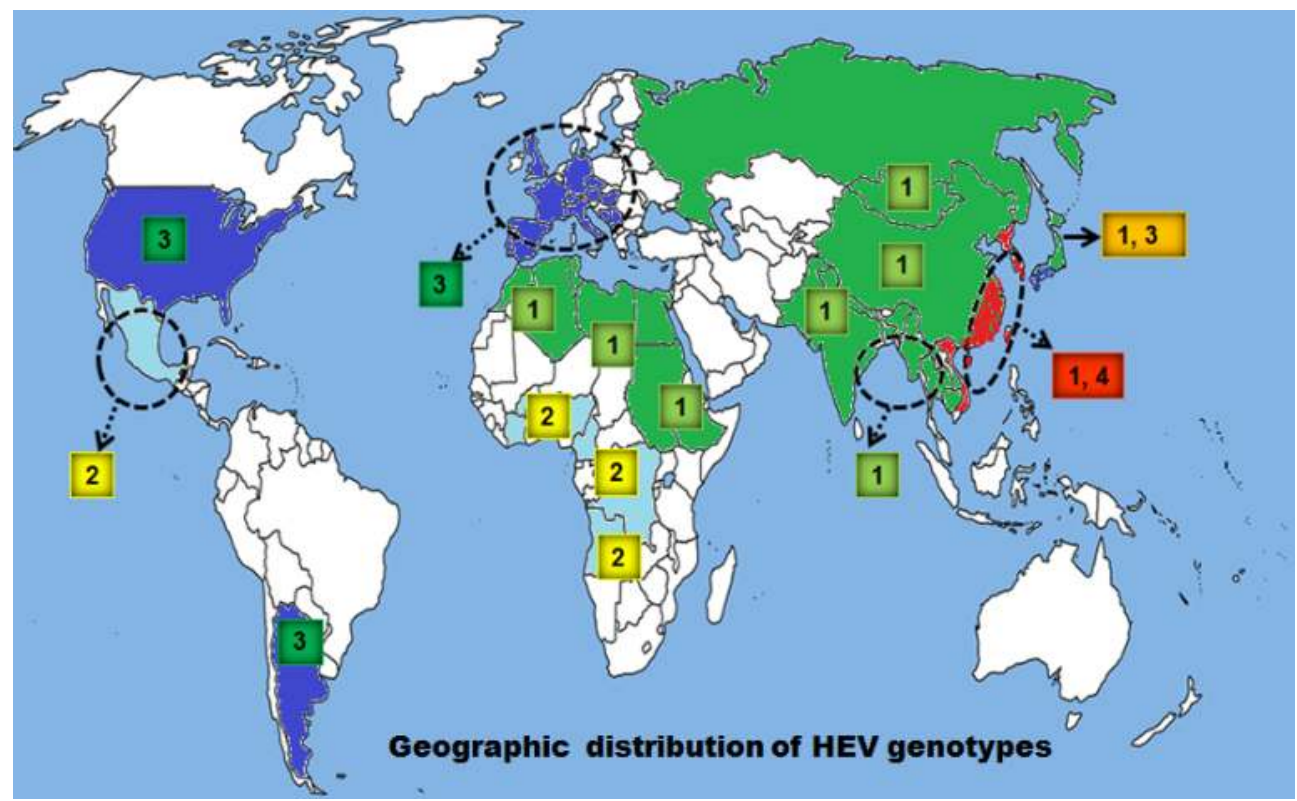

Figure 14. Worldwide geographic distribution of HEV: (Adapted from: Ref. 230,231,233,234 \& 236)

\subsection{HEV genotype and antiviral treatment response}

Since most of the cases are self-limiting, acute HEV does not require antiviral therapy in immunocompetent patients related to any genotype. The immunosuppressed patients should be recommended ribavirin, so that these patients should not progressed to cirrhosis. Liver transplantation is the only treatment option for patients with fulminant hepatic failure due to HEV. All the four mammalian HEV strains belong to one serotype. Thus, only one hepatitis E vaccine is needed for broad protection. The first phase of the immunoprophylaxis of HEV is already tested for safety and immunogenicity [244]. The next phase is to make it available in the market, especially in developing countries so that it should be effectively controlled.

\section{Conclusions}

The analysis of genomic sequence heterogeneity among different isolates of hepatitis viruses (A-E) may provide an opportunity to decipher the course and pathogenesis of the virus. Although, lot of information are available in this area but still there are many contradictions and discrepancies.

HAV: There are contradictory findings regarding the role of nucleotide substitutions and genotypic variations in disease severity among patients contracted with hepatitis A in different geographical location. 
HBV: There are conflicting report about the role of HBV genotypes and severity of the disease based on geographical distribution. Based on multiple studies, compared to genotype A and B patients, C and D patients have a higher risk of disease progression (i.e. cirrhosis \& HCC). Similarly, genotype A and B patients responded better to interferon therapy than C and D patients. It is important to note that few studies find no association between genotypes, disease severity and response to treatment regimen.

HCV: Patients infected with any of the $6 \mathrm{HCV}$ genotype can develop advanced liver disease, including cirrhosis and HCC. However, some genotypes appear to be more severe compared to the other. For example, genotype $1 \mathrm{~b}$ is reported to be associated with a more severe and a more aggressive course compared to genotype 2. Presently, it is recommended all the patients irrespective of genotype should be given treatment, however treatment length depends on the virus genotype.

HDV: There are contradictory outcomes about the role of HDV genotypes and disease severity. At one geographical location HDV genotype 1 is associated with fulminant hepatitis and HCC while at another location it is not severe. Other genotypes of HDV also have variable disease severity based on geographical location.

HEV: Although HEV is self-limiting illness still it causes severe illness in pregnant women with high mortality rate. Most of the pregnant women with aggressive course of the disease are associated with genotype 1 . There are lack of information regarding severity in pregnant women and other genotypes. There are contradictory report regarding the severity of disease and genotype 3 and 4, although a report from Japan suggests, silent substitutions of U3148 and C5907 in the genotype 3 and 4 with response to fulminant hepatitis.

Therefore, the genomic heterogeneity of hepatitis viruses is not the only critical factor that leads to disease progression, severity and final outcome. Hence, in combination with viral genomic heterogeneity other factors such as age, sex, geographical distribution, genetic polymorphism and host immune elements may play a vital role in deciding the clinical implications and final outcome of the infection.

\section{Author details}

Zahid Hussain*

Centre of Excellence in Biotechnology Research, King Saud University, Riyadh, Saudi Arabia

\section{References}

[1] Feinstone, S, Kapikian, M, Purcell, A, Z, \& Hepatitis, R, H. A: detection by immune electron microscopy of a virus like antigen associated with acute illness. Science, 182, 1026 
[2] World Health Organization(2000). Hepatitis A vaccines. Wkly Epidemiol Rec , 75, 38-44.

[3] Craig, A, \& Schaffner, S. W. ((2004). Prevention of hepatitis A with the hepatitis A vaccine. N Engl J Med350476481

[4] Wasley, A, Fiore, A, Bell, B, \& Hepatitis, P. A in the era of vaccination. Epidemiol Rev. 28101111

[5] Jacobsen, K, Wiersma, H, \& Hepatitis, S, T. A virus seroprevalence by age and world region, 1990 and 2005. Vaccine 2866536657

[6] Feinstone, S.M. 1996 Hepatitis A Epidemiology and prevention. Eur J Gastroenterol Hepatol , 8, 300-5.

[7] Marinho, R, Valente, T, Ramalho, A, R, \& De Moura, F,J. M, C. ((1997). The changing epidemiological pattern of hepatitis A in Lisbon, Portugal. Eur J Gastroenterol Hepatol , 9, 795-797.

[8] Hussain, Z, Das, B, Husain, C, Murthy, S, A, \& Kar, N, S. Increasing trend of acute hepatitis $A$ in north India: need for identification of high-risk population for vaccination. J Gastroenterol Hepatol 21, 689-693, 2006.

[9] Arankalle, V, Chadha, A, Chitambar, M, S, Walimbe, S, D, Chobe, A, M, \& Gandhe, L, P. S, S. ((2001). Changing epidemiology of hepatitis A and E in urban and rural India (1982-1998). J Viral Hepat 8293303

[10] Hollinger, F. B, \& Ticehurst, J.R. 1996 Hepatitis A VirusFields Virology, 3rded.; Fields, B.N., Knipe, D.M., Howley, O.M., et al. Eds.; Lippincott Williams \& Wilkins: Philadelphia, NY, USA, , 735-782.

[11] Debray, D, Cullufi, P, Devictor, D, Fabre, M, \& Bernard, O. (1997). Liver failure in children with hepatitis A. Hepatology , 26, 1018-1022.

[12] Koff, R, Hepatitis, S, \& , A. 351, 1643-1649.

[13] Grady, O, Schalm, J, G, \& Williams, S,W. R. ((1993). Acute liver failure: redefining the syndromes. Lancet, 273275, 342

[14] Takashaki, Y, \& Okuda, K. (1993). Fulminant and subfulminant hepatitis in Japan. Indian J Gastroenterol121921

[15] Acharya, S, Dasarathy, K, Kumer, S, et al. (1996). Fulminant hepatitis in a tropical population: clinical course, cause, and early predictors of outcome. Hepatology, 23, 1448-1455.

[16] Keeffe, E. B. ((1995). Is hepatitis A more severe in patients with chronic hepatitis B and other chronic liver disease? Am J Gastroenterol , 90, 201-205. 
[17] Vento, S, Garofano, T, Rezzini, C, Cainelli, F, Casali, F, Ghirozi, G, Ferraro, T, \& Concai, E. (1998). Fulminant hepatitis associated with hepatitis A virus superinfection in patients with chronic C. N Engl J Med, , 29, 286-290.

[18] Najarian, R, Caput, D, Gee, W, et al. (1985). Primary structure and gene organization of human hepatitis A virus. Proc. Natl. Acad. Sci. USA8226272631

[19] Borman, A, \& Kean, M. K, M. (1997). Intact eukaryotic initiation factor 4G is required for hepatitis A virus internal initiation of translation. Virology237129136

[20] Totsuka, A, \& Moritsugu, Y. (1999). Hepatitis A virus proteins. Intervirology426368

[21] Chang, K, Brown, H, \& Lemon, E, A. S, M. ((1993). Cell type specific proteins which interact with the 5) non translated region of hepatitis A virus RNA. J Virol , 67, 6716-6725.

[22] Schultheiss, T, Kusov, Y, Gauss-muller, Y, \& Proteinase, V. C of hepatitis A virus (HAV) cleaves the HAV polyprotein at all sites including VP1/2A and 2A/2B. Virology198, 275-281, 2-P3.

[23] Cohen, J. I, Ticehurst, J. R, Purcell, R. H, Buckler-white, A, \& Baroudy, B. M. (1987). Complete nucleotide sequence of wild type hepatitis A virus: comparision with different strains of hepatitis A virus and other picornaviruses. J Virol615059

[24] Arauz-ruiz, P, Sundqvist, L, Garcia, Z, Taylor, L, Visona, K, Norder, H, \& Magnius, L. O. (2001). Presumed common source outbreaks of hepatitis A in an endemic area confirmed by limited sequencing within the VP1 region. J Med Virol 65449456

[25] Costa-mattioli, M, Cristina, J, Romero, H, et al. (2002). Molecular evolution of hepatitis A virus: a new classification based on the complete VP1 protein. J Virol7695169525

[26] Khanna, B, Spelbring, J. E, Innis, B. L, \& Robertson, B. H. (1992). Characterization of a genetic variant of human hepatitis A virus. J Med Virol36118124

[27] Robertson, B. H, Jansen, R. W, \& Khanna, B. (1992). Genetic relatedness of hepatitis A virus strains recovered from different geographical regions. J Gen Virol 7313651377

[28] Ching, K. Z, Nakano, T, Chapman, L. E, Demby, A, \& Robertson, B. H. (2002). Genetic characterization of wild-type genotype VII hepatitis A virus. J Gen Virol 835360

[29] Jansen, R. W, Siegl, G, \& Lemon, S. M. (1990). Molecular epidemiology of human hepatitis A virus defined by an antigen-capture polymerase chain reaction method. Proc. Natl. Acad. Sci. USA8728672871

[30] Costa-mattioli, M. Di Napoli, A., Ferre, V., Billaudel, S., Perez-Bercoff, R., Cristina, J. (2003). Genetic variability of hepatitis A virus. J Gen Virol 8431913201

[31] Hussain, Z, Das, B. C, Husain, S. A, et al. (2005). Hepatitis A viral genotypes and clinical relevance: Clinical and molecular characterization of hepatitis A virus isolates from northern India. Hepatol Res 321624 
[32] Fujiwara, K, Yokosuka, O, Ehata, T, et al. (2002). Association between severity of type A hepatitis and nucleotide variations in the $5^{\prime}$ non-translated region of hepatitis A virus RNA: strains from fulminant hepatitis have fewer nucleotide substitutions. Gut 5, 82-88.

[33] Kanda, T, Jeong, S. H, Imazeki, F, Fujiwara, K, \& Yokosuka, O. (2010). Analysis of 5' non-translated region of hepatitis A viral RNA genotype I from South Korea: comparison with disease severities. PLoS One 5, e15139

[34] Fujiwara, K, Yokosuka, O, Imazeki, F, et al. (2003). Analysis of the genotype determining region of hepatitis A viral RNA in relation to disease severities. Hepatol Res, 25, 124-134.

[35] Rezende, G, Roque-afonso, A. M, Samuel, D, et al. (2003). Viral and clinical factors associated with the fulminant course of hepatitis A infection. Hepatology , 38, 613-618.

[36] Normann, A, Jung, C, Vallbracht, A, \& Flehmig, B. (2004). Time course of hepatitis A viremia and viral load in the blood of human hepatitis A patients. J Med Virol , 72, $10-16$.

[37] Tjon, G. M, \& Coutinho, R. A. van den Hoek A et al. ((2006). High and persistent excretion of hepatitis A virus in immunocompetent patients. J Med Virol 78, 1398-1405.

[38] Yoon, Y. K, Yeon, J. E, Kim, J. H, et al. (2011). Comparative analysis of disease severity between genotypes IA and IIIA of hepatitis A virus. J Med Virol , 83, 1308-1314.

[39] Coppola, N, Genovese, D, Pisaturo, M, et al. (2007). Acute hepatitis with severe cholestasis and prolonged clinical course due to hepatitis A virus Ia and $\mathrm{Ib}$ coinfection. Clin Infect Dis 44, ee77, 73.

[40] Tiollais, P, Pourcel, C, \& Dejean, A. (1985). The hepatitis B virus. Nature 317, 489-495.

[41] Zuckerman, A. J. (1996). Hepatitis viruses. In Baron S, et al.. Baron's Medical Microbiology (4th ed.). University of Texas Medical Branch

[42] Tibbs, C. J, \& Smith, H. M. (2001). Clinicians guide to viral hepatitis. $1^{\text {st }}$ Edition. Arnold

[43] Kao, J. H, \& Chen, D. S. (2002). Global control of hepatitis B virus infection. Lancet Infect Dis 2, 395-403.

[44] Hou, J, Liu, Z, \& Gu, F. (2005). Epidemiology and Prevention of Hepatitis B Virus Infection. International Journal of Medical Sciences , 2, 50-57.

[45] Lee, W. M. (1997). Hepatitis B virus infection. N Engl J Med , 337, 1733-1745.

[46] Alter, M. J. (2003). Epidemiology and prevention of hepatitis B. Semin liver Dis , 23, 39-46.

[47] Gust, I, \& Crowe, S. (1986). The global importance of viral hepatitis. Clin Trop Med Commun Dis , 1, 281-301. 
[48] Custer, B, Sullivan, S. D, Hazlet, T. K, Iloeje, U, Veenstra, D. L, \& Kowdley, K. V. (2004). Global epidemiology of hepatitis B virus. J Clin Gastroenterol 38, SS168, 158.

[49] Kidd-ljunggren, K, Myhre, E, \& Bläckberg, J. (2004). Clinical and serological variation between patients infected with different Hepatitis B virus genotypes. J Clin Microbiol, $42,5837-5841$.

[50] Kao, J. H. (2003). Hepatitis B virus genotypes and hepatocellular carcinoma in Taiwan. Intervirology 46, 400-407.

[51] Fattovich, G, Stroffolini, T, Zagni, I, \& Donato, F. (2004). Hepatocellular carcinoma in cirrhosis: incidence and risk factors. Gastroenterology 127, S, 35-50.

[52] Locarnini, S. A. (2002). Clinical relevance of viral dynamics and genotypes in hepatitis B virus. Journal of Gastroenterology E Hepatology 17, SS328, 322.

[53] Lavanchy, D. (2004). Hepatitis B virus epidemiology, disease burden, treatment, and current and emerging prevention and control measures. Journal of Viral Hepatitis 11, 97-107.

[54] Summers, J, \& Mason, W. S. (1982). Replication of the genome of a hepatitis B-like virus by reverse transcription of an RNA intermediate. Cell 29, 403-415.

[55] Locarnini, S. (2004). Molecular virology of hepatitis B virus. Semin Liver Dis , 24, 3-10.

[56] Beck, J, \& Nassal, M. (2007). Hepatitis B virus replication. World J Gastroenterol , 13, 48-64.

[57] Jilbert, A. R, Burrell, C. J, Triatni, M, \& Kann, M. (2002). Hepatitis B virus replication. In Hepatitis B Virus, Edited by Lai C-L \& Locarnini S. London: International Medical Press, 43-53.

[58] Seeger C \& Mason WS(2000). Hepatitis B virus biology. Microbiology \& Molecular Biology Reviews , 64, 51-68.

[59] Wu, H. L, Huang, L. R, Huang, C. C, et al. (2005). RNA interference-mediated control of hepatitis B virus and emergence of resistant mutant. Gastroenterology , 128, 708-716.

[60] Okamoto, H, Tsuda, F, Sakugawa, H, Sastrosoewignjo, R. I, Imai, M, Miyakawa, Y, \& Mayumi, M. (1988). Typing hepatitis B virus by homology in nucleotide sequence: Comparison of surface antigen subtypes. J Gen Virol , 69, 2575-2583.

[61] Cao, G. W. (2009). Clinical relevance and public health significance of hepatitis B virus genomic variations. World J Gastroenterol 15, 5761-5769.

[62] Mcmahon, B. J. (2009). The influence of hepatitis B virus genotype and subgenotype on the natural history of chronic hepatitis B. Hepatol Int 333442

[63] Kurbanov, F, Tanaka, Y, \& Mizokami, M. (2010). Geographical and genetic diversity of the human hepatitis B virus. Hepatol Res 401430 
[64] Lin, C. L, \& Kao, J. H. (2011). The clinical implications of hepatitis B virus genotype: Recent advances. J Gastroenterol Hepatol , 1, 123-30.

[65] Kao, J. H. (2002). Clinical relevance of hepatitis B viral genotypes: a case of deja vu? Journal of Gastroenterology \& Hepatology 17113115

[66] Norder, H, Courouce, A. M, Coursaget, P, Echevarria, J. M, Lee, S. D, Mushahwar, I. K, \& Robertson, B. H. Locarnini S \& Magnius LO. ((2004). Genetic diversity of hepatitis B virus strains derived worldwide: genotypes, subgenotypes, and HBsAg subtypes. Intervirology 47289309

[67] Magnius LO \& Norder H(1995). Subtypes, genotypes and molecular epidemiology of the hepatitis B virus as reflected by sequence variability of the S-gene. Intervirology 382434

[68] Mahtab, M. A, Rahman, S, Khan, M, \& Karim, F. (2008). Hepatitis B virus genotypes: an overview. Hepatobiliary Pancreat Dis Int , 7, 457-464.

[69] Alvarado Mora MV, Romano CM, Gomes-Gouvea MS, Gutierrez MF, Botelho L, Carrilho FJ, Pinho JRR. ((2011). Molecular characterization of the Hepatitis B virus genotypes in Colombia: A Bayesian inferences on the genotype F. Infection, genetics and Evolution , 11, 103-108.

[70] Stuyver, L, De Gendt, S, Van Geyt, C, Zoulim, F, Fried, M, Schinazi, R. F, \& Rossau, R. (2000). A new genotype of hepatitis B virus: completegenome and phylogenetic relatedness. J Gen Virol 816774

[71] Mizokamia, M, Nakanob, T, Oritob, E, Tanakab, Y, Sakugawac, H, Mukaided, M, Robertsone, H, \& Hepatitis, B. B virus genotype assignment using restriction fragment length polymorphism patterns. FEBS Letters 4506671

[72] Grandjacques, C, Pradat, P, Stuyver, L, Chevallier, M, Chevallier, P, Pichoud, C, Maisonnas, M, Trepo, C, \& Zoulim, F. (2000). Rapid detection of genotypes and mutations in the pre-core promoter and the pre-core region of hepatitis B virus genome: correlation with viral persistence and disease severity. J Hepatol 33, 430-439.

[73] Naito, H, Havashi, S, \& Abe, K. (2001). Rapid and specific genotyping system for hepatitis B virus corresponding to six major genotypes by PCR using type-specific primers. J Clin Microbiol 39, 1686

[74] Chu, C. J, Keeffe, E. B, Han, S. H, Perrillo, R. P, Min, A. D, Soldevila-pico, C, et al. (2003). Hepatitis B virus genotypes in the United States: results of a nationwide study. Gastroenterology , 125, 444-451.

[75] Kumar, A, Kumar, S. I, Pandey, R, Naik, S, \& Aggarwal, R. (2005). Hepatitis B virus genotype $A$ is more often associated with severe liver disease in northern India than is genotype D. Indian J Gastroenterol , 24, 19-22.

[76] Sugauchi, F, Orito, E, Ichida, T, Kato, H, Sakugawa, H, Kakumu, S, Ishida, T, Chutaputti, A, Lai, C. L, Ueda, R, Miyakawa, Y, \& Mizokami, M. (2002). Hepatitis B virus 
of genotype $\mathrm{B}$ with or without recombination with genotype $\mathrm{C}$ over the precore region plus the core gene. J Virol , 76, 5985-5992.

[77] Lin, C. L, Chen, J. D, \& Liu, C. J. (2007). Clinicopathological differences between hepatitis B viral genotype B- and C-related resectable hepatocellular carcinoma. J Viral Hepat 2007; , 14, 64-69.

[78] Zhang, H. W, Yin, J. H, \& Li, Y. T. (2008). Risk factors for acute hepatitis B and its progression to chronic hepatitis in Shanghai, China. Gut 5717131720

[79] Matsuura, K, Tanaka, Y, \& Hige, S. (2009). Distribution of hepatitis B virus genotypes among patients with chronic infection in Japan shifting toward an increase of genotype A. J Clin Microbiol 4714761483

[80] Arankalle, V. A, Murhekar, K. M, Gandhe, S. S, Murhekar, M. V, \& Ramdasi, A. Y. Padbidri VS \& Sehgal SC. ((2003). Hepatitis B virus: predominance of genotype D in primitive tribes of the Andaman and Nicobar islands, India (1989-1999). J Gen Virol 8419151920

[81] Chattopadhyay, S, Das, B. C, Hussain, Z, \& Kar, P. (2006). Hepatitis B virus genotypes in acute and fulminant hepatitis patients from north India using two different molecular genotyping approaches. Hepatol Res , 35, 79-82.

[82] Abdo, A. A, Al-jarallah, B. M, Sanai, F. M, Hersi, A. S, Al-swat, K, Azzam, N. A, Aldukhayil, M, Al-maarik, A, \& Al-faleh, F. Z. (2006). Hepatitis B genotypes: relation to clinical outcome in patients with chronic hepatitis B in Saudi Arabia. World J Gastroenterol 1270197024

[83] Sanchez-tapias, J. M, Costa, J, \& Mas, A. Bruguera M \& Rodes J. ((2002). Influence of hepatitis B virus genotype on the long-term outcome of chronic hepatitis B in western patients. Gastroenterology 12318481856

[84] Pineiro YLFGMbayed VA and Campos RH. ((2003). Evolutionary history of hepatitis $\mathrm{B}$ virus genotype F: an in-depth analysis of argentine isolates. Virus Genes 27103110

[85] Suzuki, S, Sugauchi, F, Orito, E, Kato, H, Usuda, S, Siransy, L, Arita, I, Sakamoto, Y, Yoshihara, N, \& Gohary, A. Ueda R \& Mizokami M. ((2003). Distribution of hepatitis $\mathrm{B}$ virus (HBV) genotypes among HBV carriers in the Cote d'Ivoire: complete genome sequence and phylogenetic relatedness of HBV genotype E. J Med Virol , 69, 459-465.

[86] Arauz-Ruiz, Norder PH, Robertson BH, Magnius LO, Genotype H. ((2002). A new Amerindian genotype of hepatitis B virus revealed in Central America. J Gen Virol 8320592073

[87] Kato, H, Gish, R. G, Bzowej, N, Newsom, M, Sugauchi, F, Tanaka, Y, Kato, T, Orito, E, Usuda, S, \& Ueda, R. Miyakawa Y\& Mizokami M. ((2004). Eight genotypes (A-H) of hepatitis B virus infecting patients from San Francisco and their demographic, clinical, and virological characteristics. J Med Virol 73516521 
[88] Devesa, M, Loureiro, C. L, Rivas, Y, Monsalve, F, Cardona, N, Duarte, M. C, Poblete, F, Gutierrez, M. F, Botto, C, \& Pujol, F. H. (2008). Subgenotype diversity of hepatitis $\mathrm{B}$ virus American genotype $\mathrm{F}$ in Amerindians from Venezuela and the general population of Colombia. J Med Virol , 80, 20-26.

[89] Thuy, P. T, Alestig, E, Liem, N. T, Hannoun, C, \& Lindh, M. C recombinant (putative genotype I) of hepatitis B virus is rare in Hanoi, Vietnam-genotypes B4 and C1 predominate. J Med Virol , 82, 1327-1333.

[90] Tatematsu, K, Tanaka, Y, \& Kurbanov, F. (2009). A genetic variant of hepatitis B virus divergent from known human and ape genotypes isolated from a Japanese patient and provisionally assigned to new genotype J. J Virol 831053847

[91] Sumi, H, Yokosuka, O, Seki, N, Arai, M, Imazeki, F, Kurihara, T, et al. (2003). Influence of hepatitis $\mathrm{B}$ virus genotypes on the progression of chronic type B liver disease. Hepatology , 37, 19-26.

[92] Suzuki, Y, Kobayashi, M, \& Ikeda, K. (2005). Persistence of acute infection with hepatitis B virus genotype A and treatment in Japan. J MedVirol 76, 33-39.

[93] Kao, J. H, Chen, P. J, Lai, M. Y, \& Chen, D. S. (2000). Hepatitis B genotypes correlate with clinical outcomes in patients with chronic hepatitis B. Gastroenterology , 118, 554-559.

[94] Thakur, V, Guptan, R. C, Kazim, S. N, Malhotra, V, \& Sarin, S. K. (2002). Profile, spectrum and significance of HBV genotypes in chronic liver disease patients in the Indian subcontinent. J Gastroenterol Hepatol 17, 165-70.

[95] Lindh, M, Hannoun, C, Dhillon, A. P, Norkrans, G, \& Horal, P. (1999). Core promoter mutations and genotypes in relation to viral replication and liver damage in East Asian hepatitis B virus carriers. J Infect Dis 179, 775-782.

[96] Chan, H. L, Hui, A. Y, \& Wong, M. L. (2004). Genotype C hepatitis B virus infection is associated with an increased risk of hepatocellular carcinoma. Gut 53, 1494-1498.

[97] Yuen, M. F, Sablon, E, Wong, D. K, Yuan, H. J, Wong, B. C, Chan, A. O, \& Lai, C. L. (2003). Role of hepatitis B virus genotypes in chronic hepatitis B exacerbation. Clin Infect Dis , 37, 593-597.

[98] Orito, E, Ichida, T, Sakugawa, H, Sata, M, Horiike, N, Hino, K, Okita, K, Okanoue, T, Iino, S, Tanaka, E, Suzuki, K, Watanabe, H, Hige, S, \& Mizokami, M. (2001). Geographic distribution of hepatitis $\mathrm{B}$ virus $(\mathrm{HBV})$ genotype in patients with chronic HBV infection in Japan. Hepatology 34, 590-594.

[99] Chen, Y. C, Sheen, I. S, Chu, C. M, \& Liaw, Y. F. (2002). Prognosis following spontaneous HBsAg seroclearance in chronic hepatitis B patients with or without concurrent infection. Gastroenterology 12310841089 
[100] Hsu, Y. S, Chien, R. N, \& Yeh, C. T. (2002). Long-term outcome after spontaneous HBeAg seroconversion in patients with chronic hepatitis B. Hepatology 3515221527

[101] Kao, J. H, Chen, P. J, Lai, M. Y, \& Chen, D. S. (2004). Hepatitis B virus genotypes and spontaneous hepatitis B e antigen seroconversion in Taiwanese hepatitis B carriers. $J$ Med Virol 72, 363-369.

[102] Wai, C. T, Fontana, R. J, \& Polson, J. (2005). Clinical outcome and virological characteristics of hepatitis B-related acute liver failure in the United States. J Viral Hepatol 12, 192-198.

[103] Yuen, M. F, Wong, D. K, \& Sablon, E. (2004). HBsAg seroclearance in chronic hepatitis B in the Chinese: virological, histological, and clinical aspects. Hepatology 39, 1694-1701.

[104] Imamura, T, Yokosuka, O, Kurihara, T, Kanda, T, Fukai, K, Imazeki, F, \& Saisho, H. (2003). Distribution of hepatitis B viral genotypes and mutations in the core promoter and precore regions in acute forms of liver disease in patients from Chiba, Japan. Gut , 52, 1630-1637.

[105] Yuen, M. F, Tanaka, Y, \& Mizokami, M. (2004). Role of hepatitis B virus genotypes Ba and $\mathrm{C}$, core promoter and precore mutations on hepatocellular carcinoma: a case control study. Carcinogenesis 25, 1593-1598.

[106] Sharma, S, Sharma, B, \& Singla, B. (2010). Clinical significance of genotypes and precore/basal core promoter mutations in HBV related chronic liver disease patients in North India. Dig Dis Sci 55, 794-802.

[107] Liu, S, Zhang, H, \& Gu, C. (2009). Associations between hepatitis B virus mutations and the risk of hepatocellular carcinoma: a meta-analysis. J Natl Cancer Inst 101, 1066-82.

[108] Fan, Y. F, Lu, C. C, \& Chen, W. C. (2001). Prevalence and significance of hepatitis B virus (HBV) pre-S mutants in serum and liver at different replicative stages of chronic HBV infection. Hepatology 33, 277-286.

[109] Sugauchi, F, Ohno, T, \& Orito, E. (2003). Influence of hepatitis B virus genotypes on the development of pre-S deletions and advanced liver disease. J Med Virol 70, 537-544.

[110] Lin, C. L, Liu, C. H, \& Wendy, C. (2007). Association of pre-S deletion mutant of hepatitis B virus with risk of hepatocellular carcinoma. J Gastroenterol Hepatol 22, 1098-1103.

[111] Liu, C. J, Kao, J. H, \& Chen, D. S. (2005). Therapeutic implications of hepatitis B virus genotypes. Liver Int , 25, 1097-1107.

[112] Liu, C. J, \& Kao, J. H. (2008). Genetic variability of hepatitis B virus and response to antiviral therapy. Antivir Ther 13, 613-624. 
[113] Kao, J. H, Wu, N. H, Chen, P. J, Lai, M. Y, \& Chen, D. S. (2000). Hepatitis B genotypes and the response to interferon therapy. J Hepatol 339981002

[114] Hou, J, \& Schilling, R. Janssen HLA. ((2001). Molecular characteristics of hepatitis B virus genotype A confer a higher response to interferon treatment. J Hepatol 34, 15

[115] Wai, C. T, Chu, C. J, Hussain, M, \& Lok, A. S. (2002). HBV genotype B is associated with better response to interferon therapy in $\mathrm{HBeAg}(+)$ chronic hepatitis than genotype C. Hepatology 36, 1425-1430.

[116] Erhardt, A, Blondin, D, \& Hauck, K. (2005). Response to interferon alfa is hepatitis B virus genotype dependent: genotype $\mathrm{A}$ is more sensitive to interferon than genotype D. Gut $54,1009-1013$.

[117] Buti, M, Cotrina, M, Valdes, A, Jardi, R, Rodriguez-frias, F, \& Esteban, R. (2002). Is hepatitis $\mathrm{B}$ virus subtype testing useful in predicting virological response and resistance to lamivudine? J Hepatol , 36, 445-446.

[118] Yuen, M. F, Wong, D. K, \& Sablon, E. (2003). Hepatitis B virus genotypes B and C do not affect the antiviral response to lamivudine. Antivir Ther , 8, 531-534.

[119] Choo, Q. L, Kuo, G, Weiner, A. J, Overby, L. R, Bradley, D. W, \& Houghton, M. (1989). Isolation of acDNA clone derived from a blood-borne non-A, non-B viral hepatitis genome. Science, 244, 359-362.

[120] Choo, Q. L, Richman, K. H, Han, J. H, et al. (1991). Genetic organization and diversity of the hepatitis C virus. Proc Natl Acad Sci USA, 88, 2451-2455.

[121] Van Der Poel, C. L, Reesink, H. W, Lelie, P. N, Leentvaar-kuypers, A, Choo, Q. L, Kuo, G, \& Houghton, M. (1989). Anti-hepatitis C antibodies and non-A, non-B posttransfusion hepatitis in The Netherlands. Lancet , 2, 297-298.

[122] Saeed, A. A, Al-admawi, A. M, Al-rasheed, A, Fairclough, D, Bacchus, R, Ring, C, \& Garson, J. (1991). Hepatitis C virus infection in Egyptian volunteer blood donors in Riyadh. Lancet 338, 459-460.

[123] MaheshwariA; Ray S; Thuluvath PJ. ((2008). Acute hepatitis C. Lancet , 372, 321-332.

[124] Rosen, H. R. (2011). Clinical practice. Chronic hepatitis C infection. N Engl J Med, $364,2429-2438$.

[125] Hoofnagle, J. H. (2002). Course and outcome of hepatitis C. Hepatology 36, SS29, 21.

[126] Alter, M. J, Margolis, H. S, Krawczynski, K, et al. (1992). The natural history of community-acquired hepatitis $C$ in the United States. The Sentinel Counties chronic nonA, non-B Hepatitis Study Team. N Engl J Med, 327, 1899-1905.

[127] Fattovich, G, Giustina, G, Degos, F, et al. (1997). Effectiveness of interferon alfa on incidence of hepatocellular carcinoma and decompensation in cirrhosis type C. European Concerted Action on Viral Hepatitis (EUROHEP). J Hepatol 27, 201-205. 
[128] Seeff LB \& Hoofnagle JH(2003). Appendix: The National Institutes of Health Consensus Development Conference Management of Hepatitis C 2002. Clinical Liver Disease 7, 261-287.

[129] Poynard, T, \& Yuen, M. F. Ratziu V \& Lai CL. ((2003). Viral hepatitis C. Lancet 362, 2095-2100.

[130] Zoulim, F, \& Chevallier, M. Maynard M \& Trepo C. ((2003). Clinical consequences of hepatitis C virus infection. Rev MedVirol 13, 57-68.

[131] Takamizawa, A. C, Mori, I, \& Fuke, S. (1991). Structure and organization of the hepatitis C virus genome isolated from human carriers. J Virol , 65, 1105-1113.

[132] Kato, N. (2000). Genome of human hepatitis C virus (HCV): gene organization, sequence diversity, and variation. Microb Comp Genomics , 5, 129-151.

[133] Houghton, M, Weiner, A, Han, J, Kuo, G, \& Choo, Q. L. (1991). Molecular biology of the hepatitis $C$ viruses: implications for diagnosis, development and control of viral disease. Hepatology , 14, 381-388.

[134] Weiner, A. J, Brauer, M. J, Rosenblatt, J, et al. (1991). Variable and hypervariable domains are found in the regions of HCV corresponding to the flavivirus envelope and NS1 proteins and the pestivirus envelope glycoproteins. Virology , 180, 842-848.

[135] Tsukiyama-kohara, K, Iizuka, N, Kohara, M, \& Nomoto, A. (1992). Internal ribosome entry site within hepatitis C virus RNA. J Virol , 66, 1476-1483.

[136] Ogata, N, Alter, H. J, Miller, R. H, \& Purcell, R. H. (1991). Nucleotide sequence and mutation rate of the $\mathrm{H}$ strain of hepatitis C virus. Proc Natl Acad Sci USA, 88, 3392-3396.

[137] Simmonds, P, Holmes, E. C, Cha, T. A, et al. (1993). Classification of hepatitis C virus into six major genotypes and a series of subtypes by phylogenetic analysis of the NS-5 region. J Gen Virol 74, 2391-2399.

[138] Hoofnagle, J. H. (2002). Course and outcome of hepatitis C. Hepatology 36, SS29, 21.

[139] Franco, S, Gimenez-barcons, M, Puig-basagoiti, F, et al. (2003). Characterization and evolution of NS5A quasispecies of hepatitis C virus genotype $1 \mathrm{~b}$ in patients with different stages of liver disease. J Med Virol 71, 195-204.

[140] Simmonds, P. (1995). Variability of hepatitis C virus. Hepatology , 21, 570-583.

[141] Robertson, B, Meyers, G, Howard, C, et al. (1998). Classification, nomenclature, and database development for hepatitis $\mathrm{C}$ virus (HCV) and related viruses: proposals for standardization. Arch Virol 43, 2493-503.

[142] Xavier, F, \& Bukh, J. (1998). Methods for determining the hepatitis C genotype. Viral Hepatitis Rev 4, 1-19. 
[143] Stuyver, L, Rossau, R, Wyseur, A, Duhamel, M, Vanderborght, B, Van Heuverswyn, $\mathrm{H}$, \& Maertens, G. (1993). Typing of hepatitis C virus isolates and characterization of new subtypes using a line probe assay. J Gen Virol , 74, 1093-1102.

[144] Okamoto, H, Sugiyama, Y, \& Okada, S. et al. ((1992). Typing hepatitis C virus by polymerase chain reaction with type-specific primers: application to clinical surveys and tracing infectious sources. J Gen Virol , 73, 673-679.

[145] Zein, N. N, \& Persing, D. H. (1996). Hepatitis C genotypes: current trends and future implications. Mayo Clin Proc , 71, 458-462.

[146] Zein, N. N. (2000). Clinical significance of hepatitis C virus genotypes. Clinical Microbiology Reviews 13, 223-235.

[147] Pawlotsky, J. M. (2003). Hepatitis C virus genetic variability: pathogenic and clinical implications. Clinical Liver Disease 7, 45-66.

[148] Nousbaum, J. B, Pol, S, Nalpas, B, Landais, P, Berthelot, P, \& Bréchot, C. (1995). Hepatitis $C$ virus type $1 b$ (II) infection in France and Italy. Collaborative Study Group. Ann Intern Med , 122, 161-168.

[149] Takada, N, Takase, S, Takada, A, \& Date, T. (1993). Differences in the hepatitis C virus genotypes in different countries. J Hepatol , 17, 277-283.

[150] Pawlotsky, J. M, Taskiris, L, Roudot-thoraval, F, Pellet, C, Stuyver, L, Duval, J, \& Dhumeaux, D. (1995). Relationship between hepatitis C virus genotypes and sources of infection in patients with chronic hepatitis C. J Infect Dis , 171, 1607-1610.

[151] Chamberlain, R. W, Adams, N, Saeed, A. A, Simmonds, P, \& Elliott, R. M. (1997). Complete nucleotide sequence of a type 4 hepatitis $C$ virus variant, the predominant genotype in the Middle East. J Gen Virol , 78, 1341-1347.

[152] Agha, S, Tanaka, Y, Saudy, N, et al. (2004). Reliability of hepatitis C virus core antigen assay for detection of viremia in HCV genotypes 1, 2, 3, and 4 infected blood donors: A collaborative study between Japan, Egypt, and Uzbekistan. J Med Virol 73, 216-222.

[153] Cha, T. A, Beall, E, Irvine, B, Kolberg, J, Chien, D, Kuo, G, \& Urdea, M. S. (1992). At least five related, but distinct, hepatitis C viral genotypes exist. Proc Natl Acad Sci USA , 89, 7144-7148.

[154] Blatt, L. M, Mutchnick, M. G, Tong, M. J, et al. (2000). Assessment of hepatitis C virus RNA and genotype from 6807 patients with chronic hepatitis C in United States. J Viral Hepat, 7, 196-202.

[155] Bruno, S, Silini, E, Crosignani, A, et al. (1997). Hepatitis C virus genotypes and risk of hepatocellular carcinoma in cirrhosis: a prospective study. Hepatology , 25, 754-758. 
[156] Tassopoulos, N. C, Papatheodoridis, G. V, Katsoulidou, A, et al. (1998). Factors associated with severity and disease progression in chronic hepatitis C. Hepatogastroenterology , 45, 1678-1683.

[157] Lee, C. M, Hung, C. H, Lu, S. N, et al. (2006). Viral etiology of hepatocellular carcinoma and HCV genotypes in Taiwan. Intervirology , 49, 76-81.

[158] De Mitri, M. S, Poussin, K, Baccarini, P, et al. (1995). HCV-associated liver cancer without cirrhosis. Lancet 345, 413-415.

[159] Naoumov, N. V, Chokshi, S, Metivier, E, \& Maertens, G. Johnson PJ \& Williams R. ((1997). Hepatitis C virus infection in the development of hepatocellular carcinoma in cirrhosis. J Hepatol 27, 331-336.

[160] Reid, A. E, Koziel, M. J, Aiza, I, Jeffers, L, Reddy, R, Schiff, E, \& Lau, J. Y. Dienstag JL \& Liang TJ. ((1999). Hepatitis C virus genotypes and viremia and hepatocellular carcinoma in the United States. Am J Gastroenterol 94, 1619-1626.

[161] Charlton, M. Genotype b and severity of posttransplant recurrence of hepatitis C infection-unconvictable felon or wrongly accused? Liver Transplantation 6, 243-245.

[162] Serra, M. A, \& Rodriguez, F. del Olmo JA, Escudero A \&Rodrigo JM. ((2003). Influence of age and date of infection on distribution of hepatitis $C$ virus genotypes and fibrosis stage. J Viral Hepat 10, 183-188.

[163] Hissar, S. S, Goyal, A, Kumar, M, et al. (2006). Hepatitis C virus genotype 3 predominates in North and Central India and is associated with significant histopathologic liver disease. J Med Virol , 78, 452-458.

[164] Adinolfi, L. E, Gambardella, M, Andreana, A, Tripodi, M. F, Utili, R, \& Ruggiero, G. (2001). Steatosis accelerates the progression of liver damage of chronic hepatitis C patients and correlates with specific HCV genotype and visceral obesity. Hepatology 33, 1358-1364.

[165] Zekri, A. R, Bahnassy, A. A, Shaarawy, S. M, Mansour, O. A, Maduar, M. A, Khaled, H. M, \& Ahmadi, O. (2000). Hepatitis C virus genotyping in relation to neu-oncoprotein overexpression and the development of hepatocellular carcinoma. J Med Microbiol 49, 89-95.

[166] Miller, F. D, \& Abu-raddad, L. J. (2010). Evidence of intense ongoing endemic transmission of hepatitis C virus in Egypt. Proc Natl Acad Sci USA, 107, 14757-14762.

[167] Verbeeck, J, Peigue-lafeuille, H, Ross, R. S, et al. (2008). HCV genotype 5: epidemiology and spread of an uncommon genotype. J Clin Virol , 41, 170-171.

[168] Wong, D. A, Tong, L. K, \& Lim, W. (1998). High prevalence of hepatitis C virus genotype 6 among certain risk groups in Hong Kong. Eur J Epidemiol , 14, 421-426. 
[169] Saracco, G, Olivero, A, \& Ciancio, A. Carenzi S \& Rizzetto M. ((2003). Therapy of chronic hepatitis C: a critical review. Current Drug Targets in Infectious Disorders 3, 25-32.

[170] McHutchison JG \& Fried MW(2003). Current therapy for hepatitis C: pegylated interferon and ribavirin. Clin Liver Dis 7, 149-161.

[171] Fried, M. W, Shiffman, M. L, Reddy, K. R, et al. (2002). Peginterferon alfa-2a plus ribavirin for chronic hepatitis C virus infection. N Engl J Med , 347, 975-982.

[172] Hadziyannis, S. J. Sette H Jr, Morgan TR et al. ((2004). Peginterferon-alpha2a and ribavirin combination therapy in chronic hepatitis C: A randomized study of treatment duration and ribavirin dose. Ann Intern Med , 140, 346-355.

[173] Shiffman, M. L. Di Bisceglie AM, Lindsay KL, et al. ((2004). Peginterferon alfa-2a and ribavirin in patients with chronic hepatitis $\mathrm{C}$ who have failed prior treatment. Gastroenterology 126, 1015-1023.

[174] Kamal, S. M, \& Nasser, I. A. (2008). Hepatitis C genotype 4: What we know and what we don'tyet know. Hepatology 47, 1371-1383.

[175] Nguyen, M. H, \& Keeffe, E. B. (2005). Prevalence and treatment of hepatitis C virus genotypes 4, 5, and 6. Clin Gastroenterol Hepatol 3, SS101, 97.

[176] Nguyen, M. H, Trinh, H. N, Garcia, R, Nguyen, G, Lam, K. D, \& Keeffe, E. B. (2008). Higher rate of sustained virologic response in chronic hepatitis $C$ genotype 6 treated with 48 weeks versus 24 weeks of peginterferon plus ribavirin. Am J Gastroenterol , 103, 1131-1135.

[177] Rizzetto, M, Canese, M, \& Arico, S. (1977). Immunofluorescence detection of a new antigen antibody system (Delta/anti-Delta) associated to hepatitis B virus in liver and serum of HBs Ag carriers. Gut 18, 997-1003.

[178] Sureau, C, Guerra, B, \& Lanford, R. E. (1993). Role of the large hepatitis B virus envelope protein in infectivity of the hepatitis delta virion. J Virol , 67, 366-372.

[179] Rizzetto, M, Ponzetto, A, \& Forzani, I. (1991). Epidemiology of hepatitis delta virus: overview. Prog Clin Biol Res , 364, 1-20.

[180] Taylor, J. M. (2006). Hepatitis delta virus. Virology , 344, 71-76.

[181] Radjef, N, Gordien, E, Ivaniushina, V, et al. (2004). Molecular Phylogenetic Analyses Indicate a Wide and Ancient Radiation of African Hepatitis Delta Virus, Suggesting a Delta virus Genus of at Least Seven Major Clades. J Virol , 78, 2537-2544.

[182] Gaeta, G. B, Stroffolini, T, Chiaramonte, M, et al. (2000). Chronic hepatitis D: a vanishing disease? An Italian multicenter study. Hepatology , 32, 824-827.

[183] Polish, L. B, Gallagher, M, Fields, H. A, \& Hadler, S. C. (1993). Delta hepatitis: molecular biology and clinical and epidemiological features. Clin Microbiol Rev , 6, 211-229. 
[184] Hadler, S. C. Alcala de Monzon M, Rivero D, Perez M, Bracho A, Fields H. ((1992). Epidemiology and long-term consequences of hepatitis delta virus infection in the Yucpa Indians of Venezuela. Am J Epidemiol 136, 1507-1516.

[185] Casey, J. L. (1996). Hepatitis delta virus. Genetics and pathogenesis. Clin Lab Med , 16, 451-464.

[186] Rizzetto, M. (1983). The delta agent. Hepatology , 3, 729-737.

[187] Casey, J. L, Brown, T. L, Colan, E. J, Wignall, F. S, \& Gerin, J. L. (1993). A genotype of hepatitis D virus that occurs in northern South America. Proc Natl Acad Sci USA, 90, 9016-9020.

[188] Wu, J. C, Choo, K. B, Chen, C. M, Chen, T. Z, Huo, T. I, \& Lee, S. D. (1995). Genotyping of hepatitis $\mathrm{D}$ virus by restriction-fragment length polymorphism and relation to outcome of hepatitis D. Lancet, 346, 939-941.

[189] Bonino, F, Hoyer, B, Ford, E, Shih, J. W, Purcell, R. H, \& Gerin, J. L. (1981). The delta agent: HBsAg particles with delta antigen and RNA in the serum of an HBV carrier. Hepatology , 1, 127-131.

[190] Wang, K. S, Choo, Q. L, Weiner, A. J, et al. (1986). Structure, sequence and expression of the hepatitis delta (ठ) viral genome. Nature 323, 508-514 (Erratum, 328,456, 1987)

[191] Chao, M, Hsieh, S. Y, \& Taylor, J. (1990). Role of two forms of hepatitis delta virusantigen: evidence for a mechanism of self-limiting genome replication. J Virol , 64, 5066-5069.

[192] Weiner, A. Q, Choo, L, Wang, K. S, et al. (1988). A single antigenomic open reading frame of the hepatitis delta virus encodes the epitope(s) of both hepatitis delta antigen polypeptides p27. J Virol 62, 594-599, 24and.

[193] Luo, G. X, Chao, M, Hsieh, S. Y, et al. (1990). A specific base transition occurs on replicating hepatitis delta virus RNA. J Virol , 64, 1021-1027.

[194] Yamaguchi, Y, Filipovska, J, Yano, K, et al. (2001). Stimulation of RNA polymerase II elongation by hepatitis delta antigen. Science , 293, 124-127.

[195] Le Gal FGault E, Ripault MP, Serpaggi J, Trinchet JC, Gordien E, Dény Eighth major clade for hepatitis delta virus. Emerg Infect Dis 12, 1447-1450, 2006.

[196] Wu, J. C, Chen, C. M, Sheen, I. J, Lee, S. D, Tzeng, H. M, \& Choo, K. B. (1995). Evidence of transmission of hepatitis $\mathrm{D}$ virus to spouses from sequence analysis of the viral genome. Hepatology 22, 1656-1660.

[197] Shakil, A. O, Hadziyannis, S, \& Hoofnagle, J. H. Di Bisceglie AM, Gerin JL, Casey JL. ((1997). Geographic distribution and genetic variability of hepatitis delta virus genotype I. Virology , 234, 160-167. 
[198] Zhang, Y. Y, Tsega, E, \& Hansson, B. G. (1996). Phylogenetic analysis of hepatitis D viruses indicating a new genotype I subgroup among African isolates. J Clin Microbiol , 34, 3023-3030.

[199] Niro, G. A, Smedile, A, Andriulli, A, Rizzetto, M, Gerin, J. L, \& Casey, J. L. (1997). The predominance of hepatitis delta virus genotype I among chronically infected Italian patients. Hepatology , 25, 728-734.

[200] Wu, J. C, Chiang, T. Y, \& Sheen, I. J. (1998). Characterization and phylogenetic analysis of a novel hepatitis D virus strain discovered by restriction fragment length polymorphism analysis. J Gen Virol , 79, 1105-1113.

[201] Watanabe, H, Nagayama, K, Enomoto, N, Chinzei, R, Yamashiro, T, Izumi, N, et al. (2003). Chronic hepatitis delta virus infection with genotype IIb variant is correlated with progressive liver disease. J Gen Virol 84, 3275-3289.

[202] Rizzetto, M, Hadziyannis, S, Hansson, B. G, Toukan, A, \& Gust, I. (1992). Hepatitis delta virus infection in the world: epidemiological patterns and clinical. Gastroenterol Internat , 5, 18-32.

[203] Farci, P. (2001). Treatment of chronic hepatitis D. Infections in Medicine. , 18(10)

[204] Hsu, S. C, Syu, W. J, Sheen, I. J, Liu, H. T, Jeng, K. S, \& Wu, J. C. (2002). Varied assembly and RNA editing efficiencies between genotypes I and II hepatitis D virus and their implications. Hepatology , 35, 665-672.

[205] Ma, S. P, Sakugawa, H, Makino, Y, Tadano, M, Kinjo, F, \& Saito, A. (2003). The complete genomic sequence of hepatitis delta virus genotype IIb prevalent in Okinawa, Japan. J Gen Virol , 84, 461-464.

[206] Niro, G. A, Rosina, F, \& Rizzetto, M. (2005). Treatment of hepatitis D. J Viral Hepat 12, 2-9.

[207] Panda, S. K, \& Jameel, S. (1997). Hepatitis E virus: from epidemiology to molecular biology; Vir Hep Rev 3, 227-251.

[208] Jameel, S. (1999). Molecular biology and pathogenesis of hepatitis E virus; Expert Rev Mol Med , 1-16.

[209] Emerson, S. U, \& Purcell, R. H. (2003). Hepatitis E Virus. Rev Med Virol 13, 145-154.

[210] Balayan, M. S, Andjaparidze, A. G, Savinskaya, S. S, et al. (1983). Evidence for a virus in non-A non-B hepatitis transmitted via fecal-oral route. Intervirology , 20, 23-31.

[211] Smith, J. L. (2001). A review of hepatitis E virus. J Food Prot , 64, 572-586.

[212] Suzuki, K, Aikawa, T, \& Okamoto, H. (2002). Fulminant hepatitis E in Japan. N Engl J Med 347:1456

[213] Okamoto, H, Takahashi, M, \& Nishizawa, T. (2003). Features of hepatitis E virus infection in Japan. Intern Med 42, 1065-1071. 
[214] Dalton, H. R, Bendall, R, Ijaz, S, \& Banks, M. (2008). Hepatitis E: an emerging infection in developed countries. Lancet Infect Dis , 8, 698-709.

[215] Hamid, S S, Atiq, M, Shehzad, F, Yasmeen, A, Nissa, T, Salam, A, Siddiqui, A, \& Jafri, W. (2002). Hepatitis E virus superinfection in patients with chronic liver disease; Hepatology $36,474-478$.

[216] Sheikh, A, Sugitani, M, Kinukawa, N, et al. (2002). Hepatitis e virus infection in fulminant hepatitis patients and an apparently healthy population in Bangladesh. Am J Trop Med Hyg , 66, 721-724.

[217] Khuroo, M S, Teli, M R, Skidmore, S, Sofi, M. A, \& Khuroo, M I. (1981). Incidence and severity of viral hepatitis in pregnancy. Am J Med 70, 252-255.

[218] Beniwal, M, Kumar, A, Kar, P, et al. (2003). Prevalence and severity of acute viral hepatitis and fulminant hepatitis during pregnancy: a prospective study from North India. Indian J Med Microbiol , 21, 184-185.

[219] Kumar, A, Beniwal, B, Kar, P, et al. (2004). Hepatitis E in pregnancy. Int J Gynaecol Obstet, 85, 240-244.

[220] Krawczynski, K, Aggarwal, R, \& Kamili, S. (2000). Hepatitis E; Infect Dis Clin North Am 14, 669-687.

[221] ICTV Virus Taxonomy: (2009). release"Retrieved 2011-12-02

[222] Reyes, G. R, Purdy, M. A, Kim, J. P, Luk, K. C, Young, L. M, Fry, K. E, \& Bradley, D. W. (1990). Isolation of a cDNA from the virus responsible for enterically transmitted non-A, non-B hepatitis. Science , 247, 1335-1339.

[223] Reyes, G. R, Huang, C. C, Tam, A. W, \& Purdy, M. A. (1993). Molecular organization and replication of hepatitis E virus (HEV). Arch Virol , 7, 15-25.

[224] Tam, A. W, Smith, M. M, Guerra, M. E, Huang, C. C, Bradley, D. W, Fry, K. E, \& Reyes, G. R. (1991). Hepatitis E virus (HEV): molecular cloning and sequencing of the full-length viral genome; Virology 185, 120-131.

[225] Tam, A. W, White, R, Reed, E, Short, M, Zhang, Y, Fuerst, T. R, \& Lanford, R. E. (1996). In vitro propagation and production of hepatitis $E$ virus from in vivo-infected primary macaque hepatocytes; Virology 215, 1-9.

[226] Ansari, I H, Nanda, S K, Durgapal, H, Agrawal, S, Mohanty, S K, Gupta, D, Jameel, S, \& Panda, S. K. (2000). Cloning, sequencing, and expression of the hepatitis E virus (HEV) nonstructural open reading frame 1 (ORF1); J Med Virol 60, 275-283.

[227] Zafrullah, M, Ozdener, M H, Kumar, R, Panda, S K, \& Jameel, S. (1999). Mutational analysis of glycosylation, membrane translocation, and cell surface expression of the hepatitis E virus ORF2 protein; J Virol 73, 4074-4082. 
[228] Graff, J, Torian, U, Nguyen, H, \& Emerson, S. U. (2006). A bicistronic subgenomic mRNA encodes both the ORF2 and ORF3 proteins of hepatitis E virus; J Virol 80, 5919-5926.

[229] Schlauder, G. G, \& Mushahwar, I. K. (2001). Genetic heterogeneity of hepatitis E virus. J Med Virol 65, 282-292.

[230] Okamoto, H. (2007). Genetic variability and evolution of hepatitis E virus. Virus Res , $127,216-228$.

[231] Purcell, R. H, \& Emerson, S. U. (2008). Hepatitis E: an emerging awareness of an old disease. J Hepatol , 48, 494-503.

[232] Lam, W. Y, Chan, R. C, Sung, J. J, \& Chan, P. K. (2009). Genotype distribution and sequence variation of hepatitis E virus, Hong Kong. Emerg Infect Dis , 15, 792-794.

[233] Arankalle, V. A, Chobe, L. P, Joshi, M. V, Chadha, M. S, Kundu, B, \& Walimbe, A. M. (2002). Human and swine hepatitis E virus from Western India belong to different genotypes. J Hepatol , 36, 417-425.

[234] Cooper, K, Huang, F. F, Batista, L, et al. (2003). Identification of genotype 3 hepatitis E virus (HEV) in serum and fecal samples from pigs in Thailand and Mexico, where genotype 1 and $2 \mathrm{HEV}$ strains are prevalent in the respective human populations. $J$ Clin Microbiol , 43, 1684-1688.

[235] Meng, X. J, Halbur, P. G, Shapiro, M. S, et al. (1998). Genetic and experimental evidence for cross-species infection by swine hepatitis E virus. J Virol , 72, 9714-9721.

[236] Ohnishi, S, Kang, J. H, Maekubo, H, et al. (2006). Comparison of clinical features of acute hepatitis caused by hepatitis E virus (HEV) genotypes 3 and 4 in Sapporo, Japan. Hepatol Res , 36, 301-307.

[237] Chobe, L. P, Lole, K. S, \& Arankalle, V. A. (2006). Full genome sequence and analysis of Indian swine hepatitis E virus isolate of genotype 4. Vet Microbiol 114, 240-251.

[238] Viswanathan, R. (1957). Infectious hepatitis in Dehli (1955-56): a critical study; epidemiology. Indian J Med Res , 45, 1-30.

[239] Kar, P, Jilani, N, Husain, S. A, Pasha, S. T, Anand, R, Rai, A, \& Das, B. C. (2008). Does hepatitis $\mathrm{E}$ viral load and genotypes influence the final outcome of acute liver failure during pregnancy? Am J Gastroenterol , 103, 2495-2501.

[240] Mizuo, H, Yazaki, Y, Sugawara, K, Tsuda, F, Takahashi, M, Nishizawa, T, \& Okamoto, H. (2005). Possible risk factors for the transmission of hepatitis $E$ virus and for the severe form of hepatitis E acquired locally in Hokkaido, Japan. J Med Virol , 76, 341-349.

[241] Abe, T, Aikawa, T, Akahane, Y, Arai, M, Asahina, Y, Atarashi, Y, et al. (2006). Demographic, epidemiological, and virological characteristics of hepatitis E virus infec- 
tions in Japan based on 254 human cases collected nationwide [in Japanese]. Kanzo., 47, 384-91.

[242] Péron, J. M, Bureau, C, Poirson, H, et al. (2007). Fulminant liver failure from acute autochthonous hepatitis $\mathrm{E}$ in France: description of seven patients with acute hepatitis E and encephalopathy. J Viral Hepat, 14, 298-303.

[243] Inoue, J, Takahashi, M, Mizuo, H, Suzuki, K, Aikawa, T, Shimosegawa, T, \& Okamoto, H. (2009). Nucleotide substitutions of hepatitis E virus genomes associated with fulminant hepatitis and disease severity. Tohoku J Exp Med 218, 279-284.

[244] Shrestha, M. P, Scott, R. M, \& Joshi, D. M. Mammen MP Jr, Thapa GB, ThapaN, et al. ((2007). Safety and efficacy of a recombinant hepatitis E vaccine.N Engl J Med, 356, 895-903. 